\title{
Chemical Composition and Biological Activities of Essential Oils in the Family Lauraceae: A Systematic Review of the Literature
}

\author{
Authors \\ Carolina Sette Barbosa Damasceno, Natasha Tiemi Fabri Higaki, Josiane de Fátima Gaspari Dias, Marilis Dallarmi Miguel, \\ Obdulio Gomes Miguel
}

Affiliation

Postgraduate Program in Pharmaceutical Sciences, Federal University of Parana, Curitiba, Parana, Brazil

\section{Key words}

Lauraceae, $\beta$-caryophyllene, 1,8-cineole, antioxidant, antimicrobial

\author{
received March 18, 2019 \\ revised May 23, 2019 \\ accepted May 28, 2019 \\ Bibliography \\ DOI https://doi.org/10.1055/a-0943-1908 \\ Published online July 1, 2019 | Planta Med 2019; 85: 1054- \\ 1072 @ C Georg Thieme Verlag KG Stuttgart · New York | \\ ISSN 0032-0943 \\ Correspondence \\ Carolina Sette Barbosa Damasceno \\ Postgraduate Program in Pharmaceutical Sciences, \\ Department of Pharmacy, Federal University of Parana \\ Av. Pref. Lothário Meissner, 632, CEP 80210-170 Curitiba, \\ Parana, Brazil \\ Phone: + 5541997545061, Fax: + 554133604098 \\ carolsete@hotmail.com
}

\section{ABSTRACT}

The Lauraceae family is predominantly found in Asia and in the rainforests of the Americas, and consists mostly of aromatic trees. Being an essential oil producer, this family is used in the food, pharmaceutical, and cosmetic industries. This work presents a systematic review of the chemical composition and bioactivity of the essential oils from the Lauraceae family. Medline, Scielo, Web of Science, Lilacs, and Scopus were employed to identify articles published between 2000 and 2018, using "Lauraceae", "essential oil”, and "biological activity" as key words. From 177 studies identified, 53 met the inclusion criteria. These studies indicated a predominance of the compounds $\beta$-caryophyllene and 1,8-cineole in Lauraceae species, and highlighted the antioxidant, antifungal, antibacterial, and anti-inflammatory activities. Essential oils extracted from this family thus have high potential for pharmacological applications.

\section{Introduction}

Lauraceae, one of the most primitive families of plants, belongs to the Magnoliidae subclass and has a tropical and subtropical distribution, predominantly in Asia and the tropical forests of the Americas. With the exception of the Cassytha genus, composed of parasitic vines, the family comprises trees and shrubs [1,2]. The economic importance of this botanical family lies in that many species are used in industrial sectors such as the food, timber, pharmaceutical, and perfumery industries. Regarding its ethnobotany, Lauraceae species have been applied to multiple different pathologies. Salleh et al. [3] outlined several medicinal uses for the genus Beilschmiedia, such as in the treatment of infectious diseases, malaria, analgesic, gastrointestinal infections, female genital infections, and rheumatism, among others.

Regarding the secondary metabolites in Lauraceae, neolignans have significant chemotaxonomic potential [4]. The isoquinolinic alkaloids are also widely representative of the family [5], as are essential oils (EOs) [6]. EOs are a mixture of active chemical substances with low molecular weight, some highly volatile, characterized by a strong odor, and are capable of providing flavor and/ or aroma [7]. The composition of EOs includes a wide range of compounds, including terpene hydrocarbons, simple and terpene alcohols, aldehydes, ketones, phenols, esters, ethers, organic acids, and lactones [8]. Of these compounds, terpenes are the main constituent of EOs and their applications, including being the active ingredients in nanostructured systems to improve the physicochemical properties and/or achieve greater bioavailability in the controlled release of drugs [9].

The terpene group is derived from isopentenyl diphosphate (IDP). This substance comes from two different biosynthetic routes, both originating from glucose: mevalonate and desoxy-xylulose phosphate pathways [10]. Terpenes are classified according to the number of isoprene units in their structure: isoprenes or 
hemiterpenes $(5 C)$, monoterpenes (10C), sesquiterpenes (15C), diterpenes (20C), sesterpenes (25C), triterpenes (30C), tetraterpenes (40C), and polysoprenoids, when there are more than 35 carbons [11]. In the Lauraceae family, there is a predominance of sesquiterpenes, mainly, sesquiterpene hydrocarbons [12]. The objective of this review involved surveying the chemical composition of EOs from species of Lauraceae, as well as their attributed bioactivity.

\section{Search Strategy}

This systematic review was conducted through searches using Medline, Scielo, Web of Science, Lilacs, and Scopus in July 2018. The key words used were "Lauraceae", "essential oil”, and "biological activity", and articles were required to have been published during the period of 18 years between January 2000 and July 2018. Key words were used only in English. A manual search was performed in bibliographic references from the articles found.

The inclusion of articles considered the following criteria: (1) type of publication - original journal articles, (2) only articles in English, Portuguese, and Spanish, (3) articles must present the chemical composition of the essential oil, (4) articles must discuss biological activity, and (5) studies used both in vivo and in vitro assays.

As exclusion criteria, the following were used: (1) articles in languages apart from English, Portuguese, and Spanish, (2) review articles, (3) full text articles not found, (4) articles without one of the key words, (5) articles discussing a mixture of plants, and (6) articles that did not present the composition of the EOs.

The first step was to exclude duplicate articles. Titles and abstracts were then read and the inclusion and exclusion criteria were applied. All articles resulting from this stage were read in full and the inclusion and exclusion criteria were applied again. Following this step, we reached the articles chosen for the present study.

For data collection, a tool was elaborated with the following information: author, date, plant, major constituents, quantification of constituents, EO extraction method, constituent identification method, and biological activities.

\section{Results and Discussion}

Based on the described criteria, 121 articles were selected after eliminating 56 duplicates. The analysis of titles and abstracts excluded 43 further articles, leaving 78 eligible articles, of which 25 were excluded after reading the full text version. Thus, 53 articles comprised the present study, written between 2002 and 2018. Fig. 1 summarizes the selection process.

- Table 1 presents data for each species with the respective chemical constituents and bioactivity. $\mathbf{\text { Table }} 2$ shows the chemical structure of the major compounds. $>$ Fig. 2 displays the percentage of the major compounds found in the evaluated articles.

As shown in - Fig. 2, $\beta$-caryophyllene and 1,8-cineole are the predominant components in the Lauraceae family. trans-Caryophyllene, a synonym of E-caryophyllene, $\beta$-caryophyllene, and trans- $\beta$-caryophyllene, is a bicyclic sesquiterpene characterized by numerous EOs and its strong odor. It is applied commercially

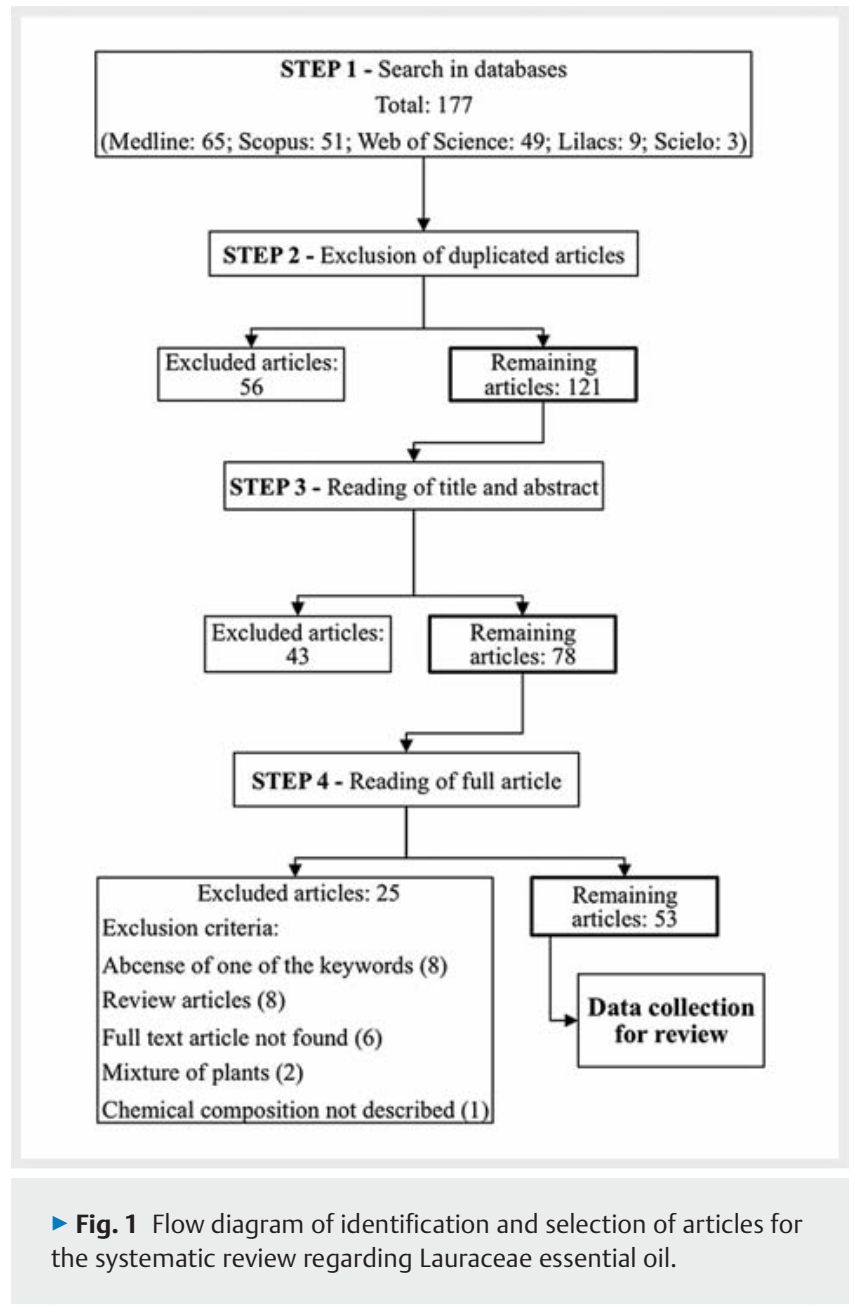

in the food and cosmetic sectors as a flavoring, a fragrance fixer in perfumes, and in personal hygiene products [65]. Furthermore, this substance has demonstrated pharmacological potential by virtue of its anti-inflammatory [66], neuroprotective [67], anticancer, antioxidant, antimicrobial [68], and antinociceptive [69] activities, among others.

The bicyclic monoterpene 1,8-cineole, also known as eucalyptol, presents different pharmacological activities, and studies on this compound mostly focus on the therapeutic treatment of severe pulmonary diseases. Clinical studies have demonstrated improvements in the treatment of chronic obstructive pulmonary disease using 1,8-cineole when compared to a placebo group [70]. Another study suggested anti-inflammatory activity of this monoterpene in asthma as a mucolytic agent in upper and lower airway diseases [71]. Other research corroborates these results by reporting mucolytic, bronchodilator, and anti-inflammatory activities [72-74].

Tied in third place are the substances linalool, $\delta$-cadinene, and $\alpha$-pinene. Linalool, an acyclic monoterpene, is a major component of EOs from different aromatic species. Similar to $\beta$-caryophyllene, linalool is used in the food and cosmetic industries, especially in perfumes and other general cosmetics [75]. Among its described utilities are that it is an antidepressive [76], is neuroprotective [77], and can prevent Alzheimer's disease [78]. Regarding the 


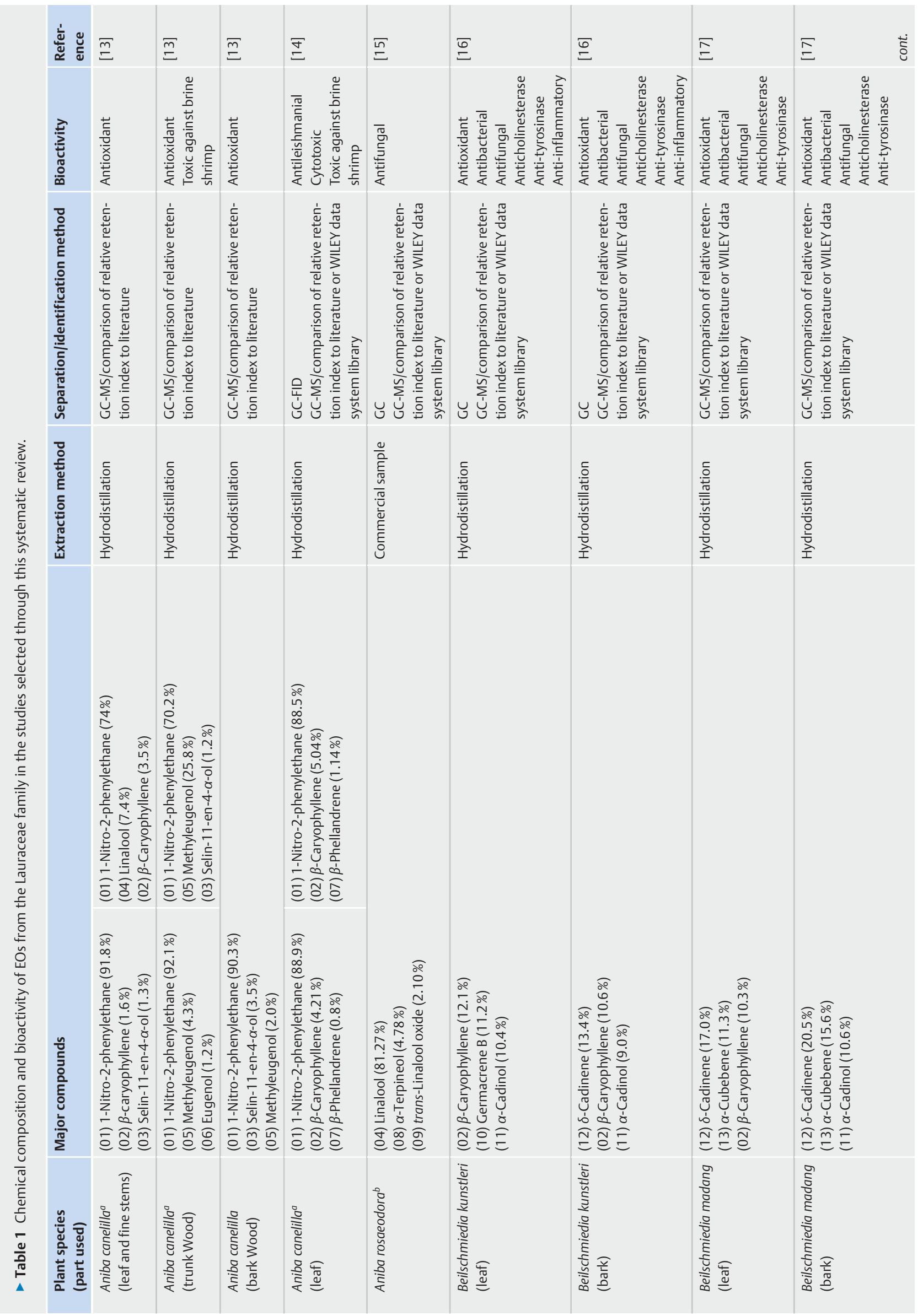




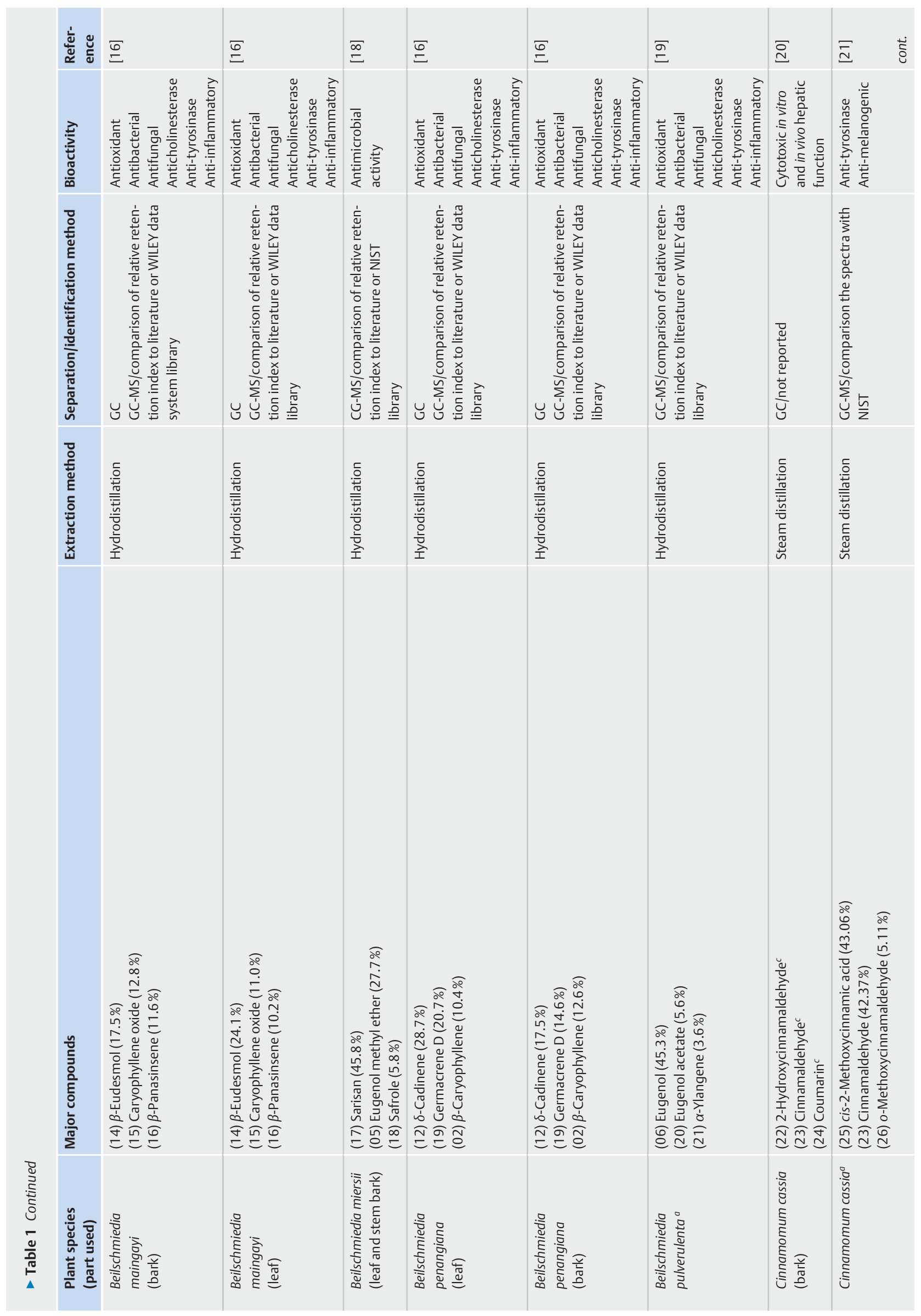




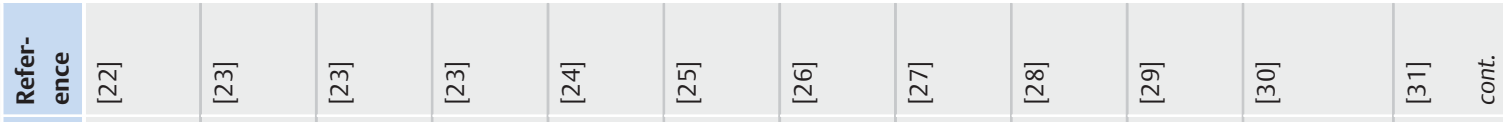

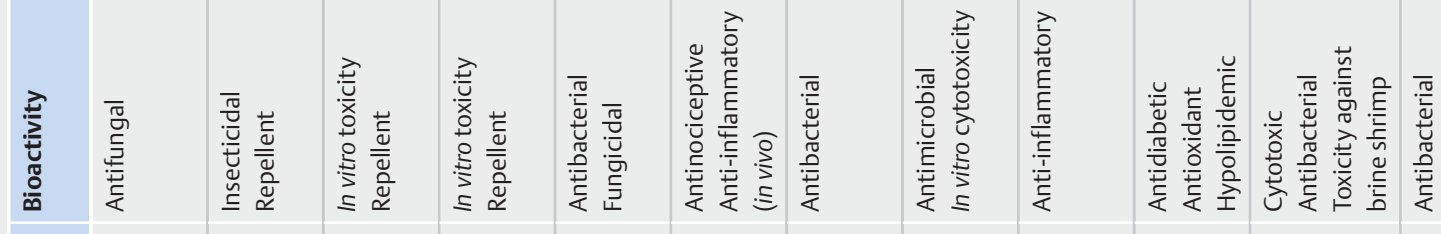

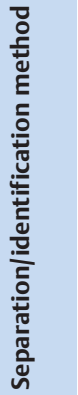

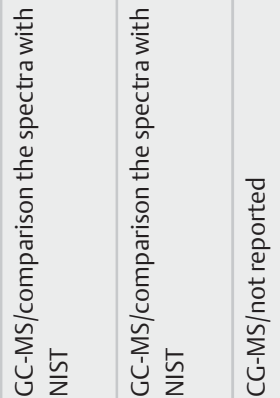

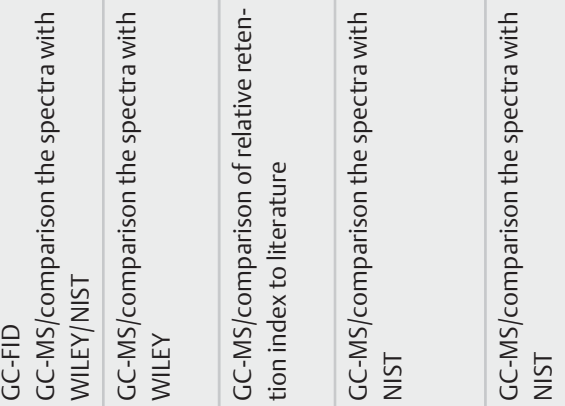

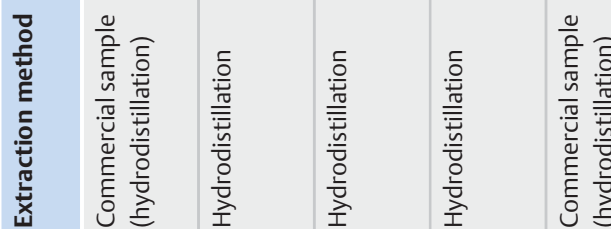
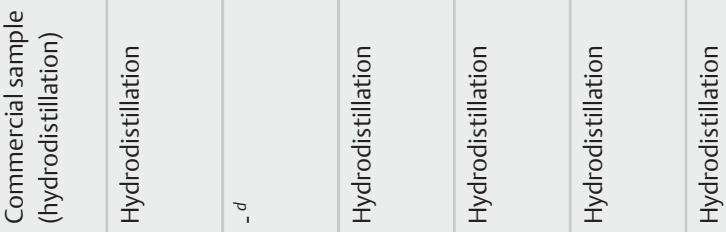

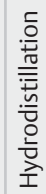

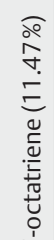
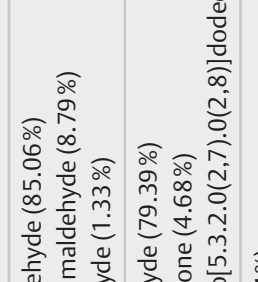

n

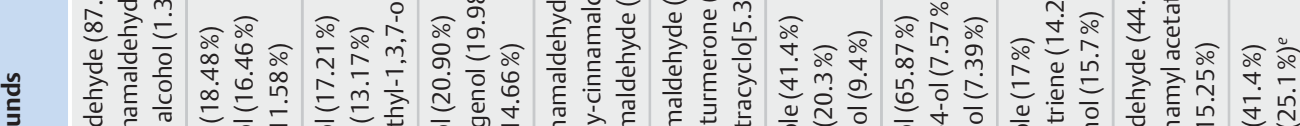

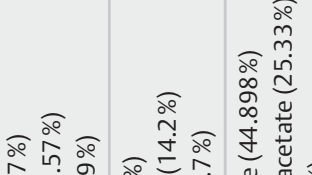

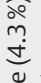

泡西

\begin{tabular}{lll} 
& \\
\hline
\end{tabular}

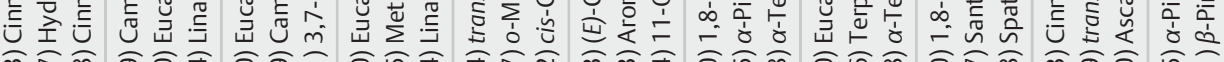

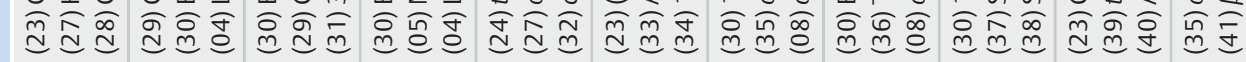

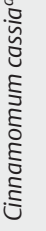
है

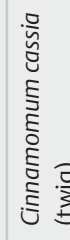

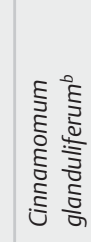

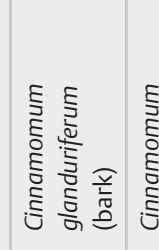
竞

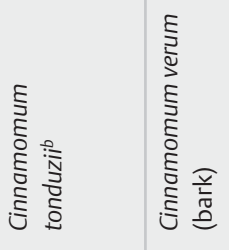




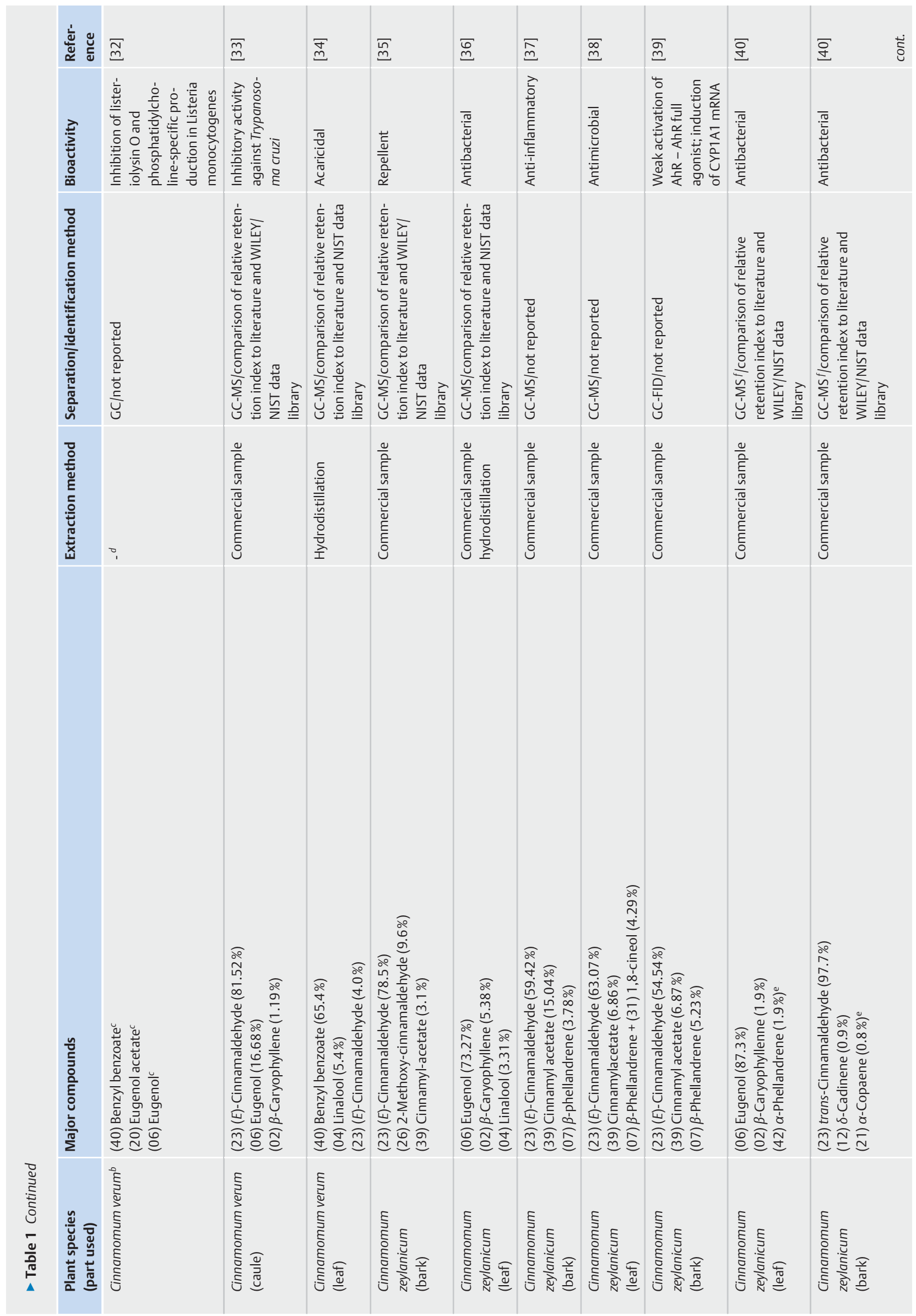




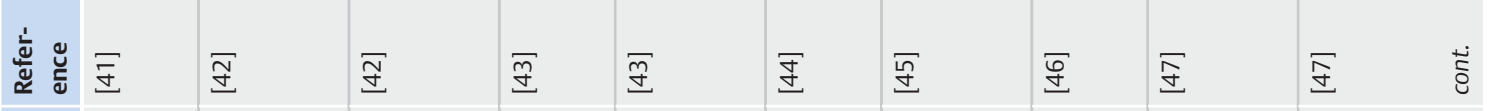

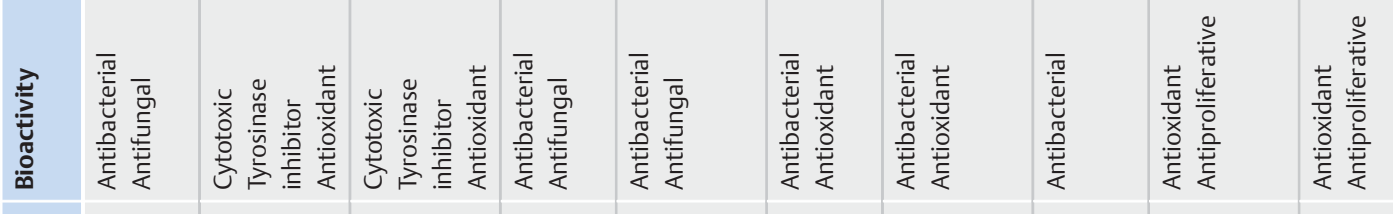
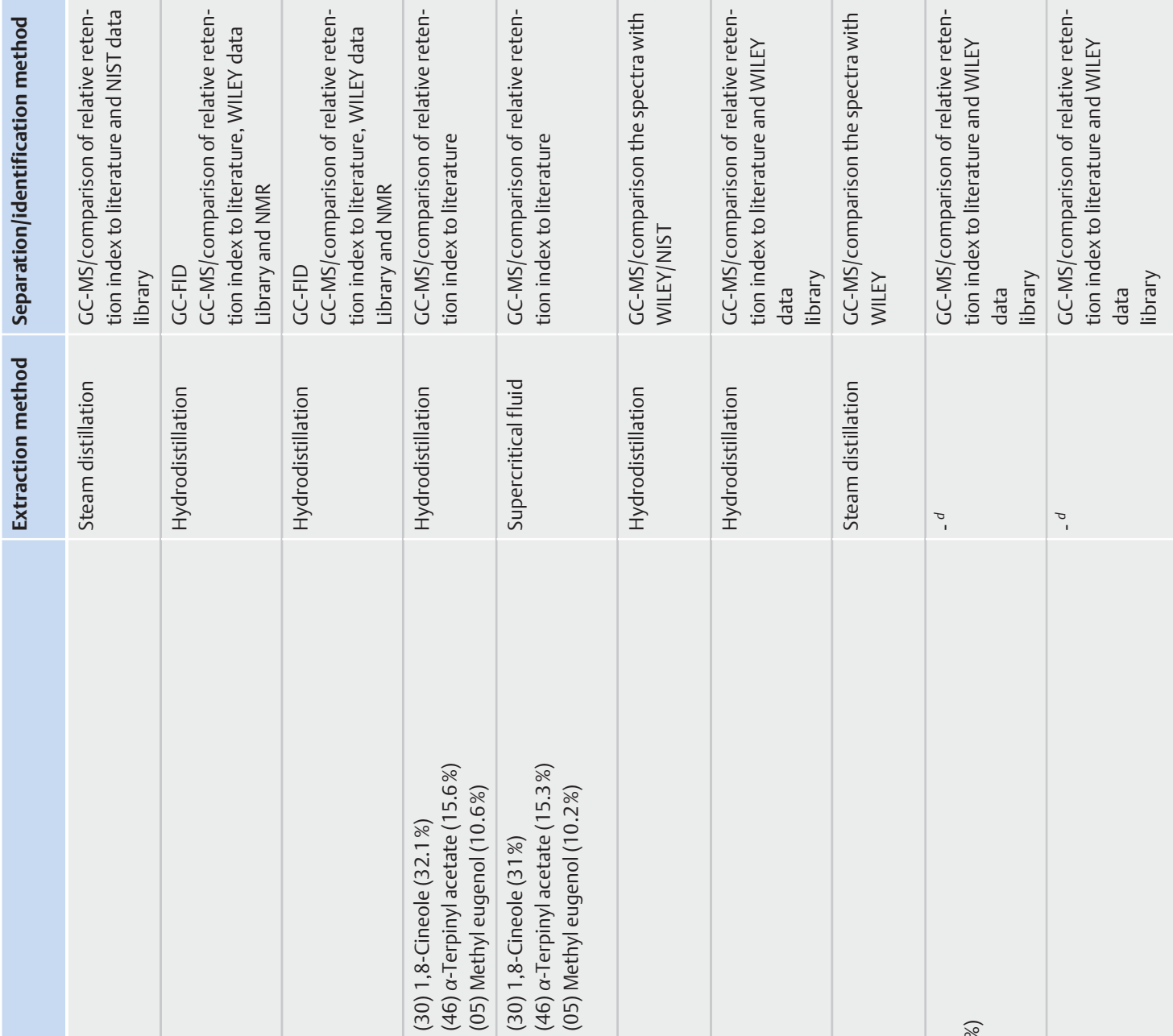

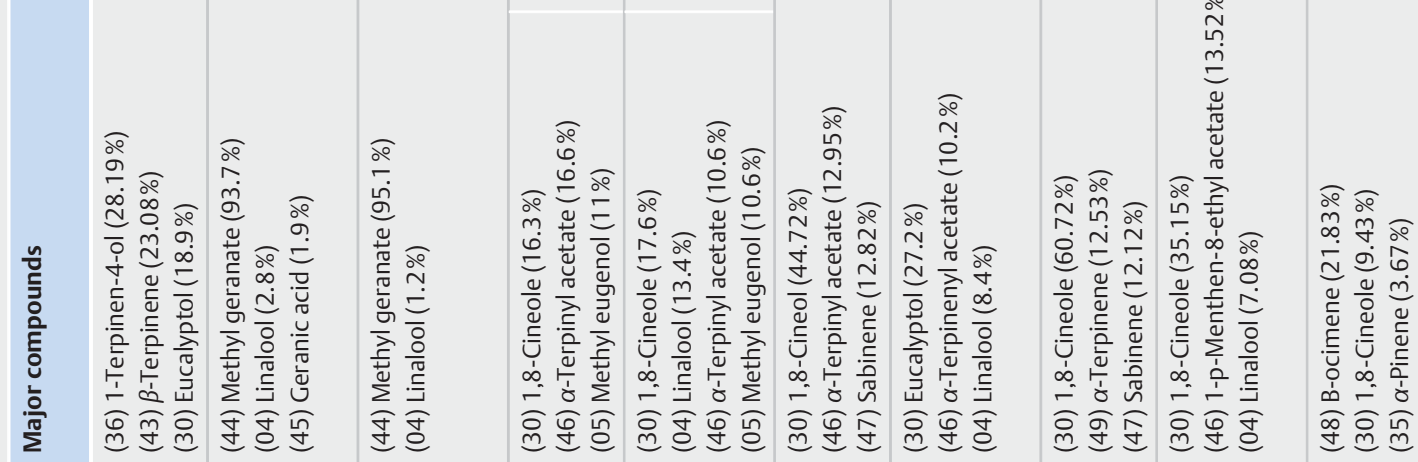




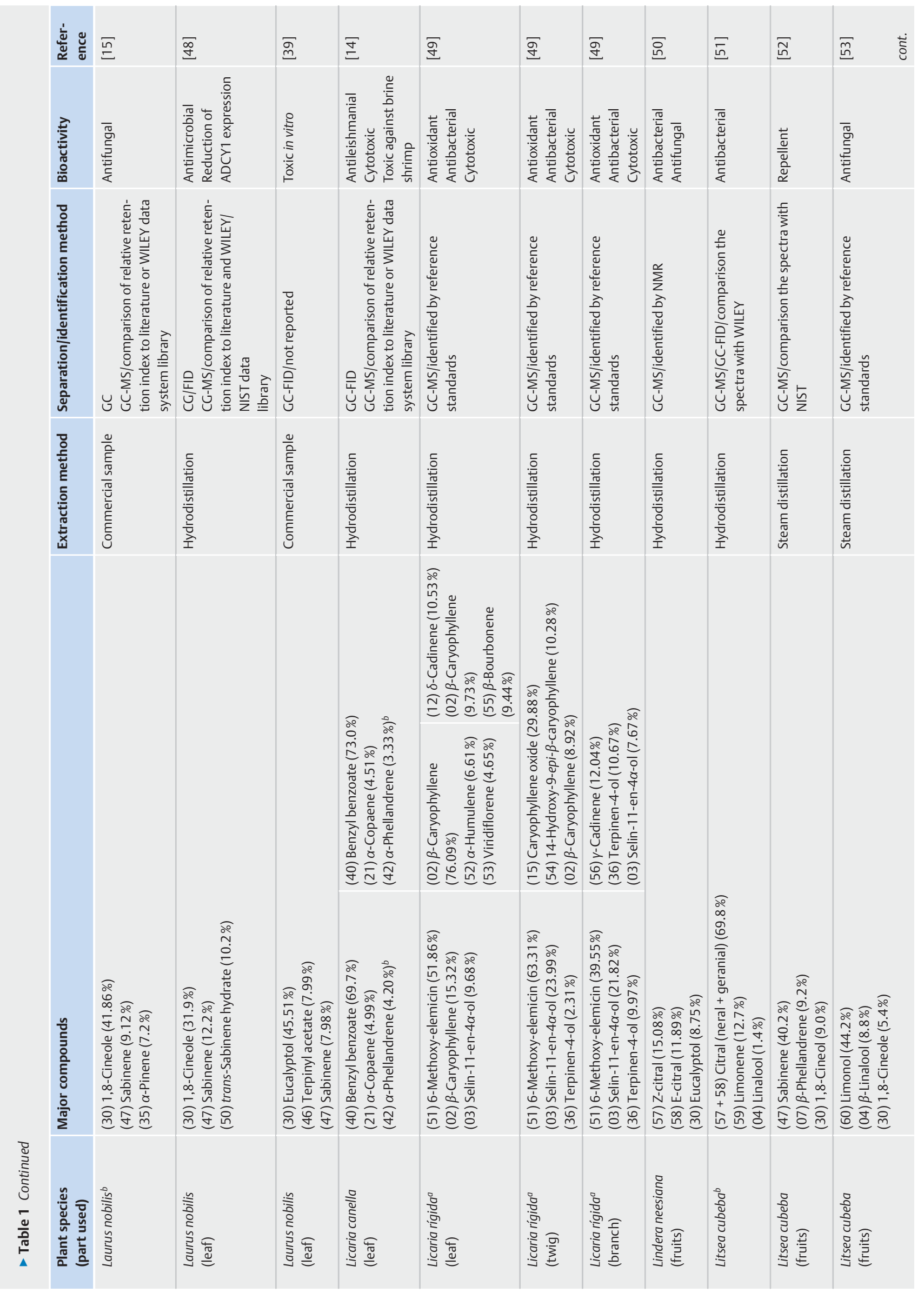




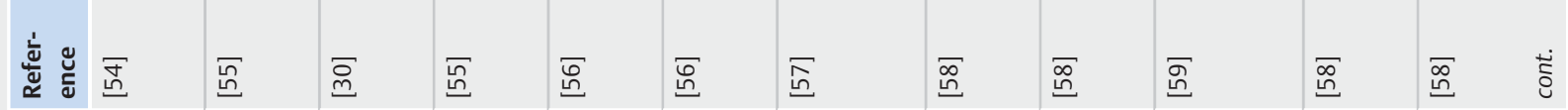

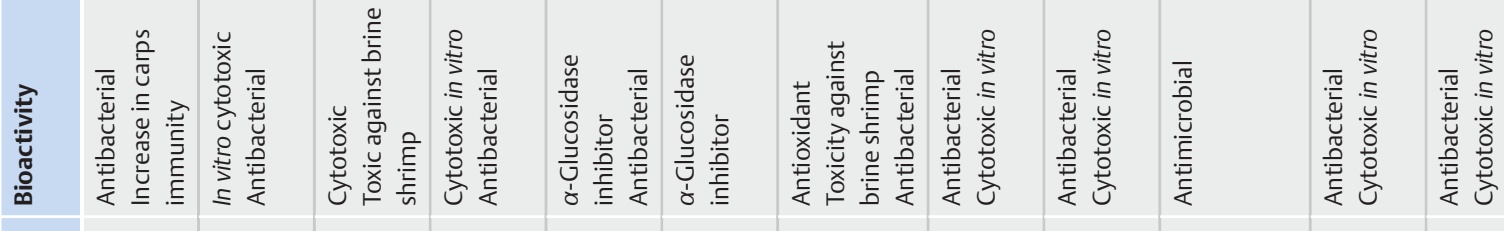

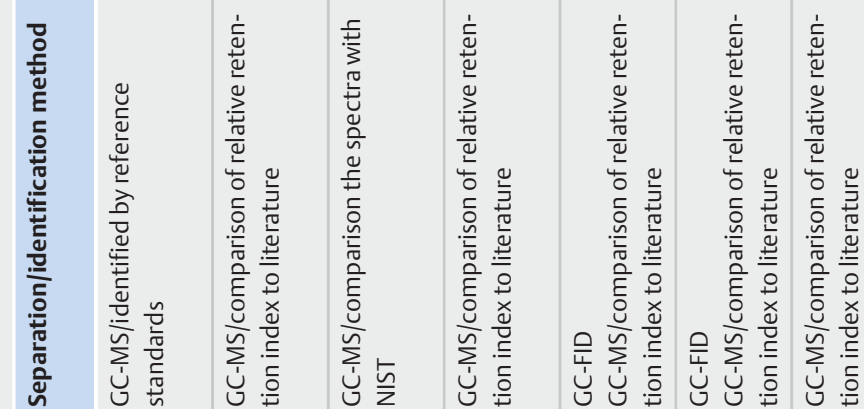

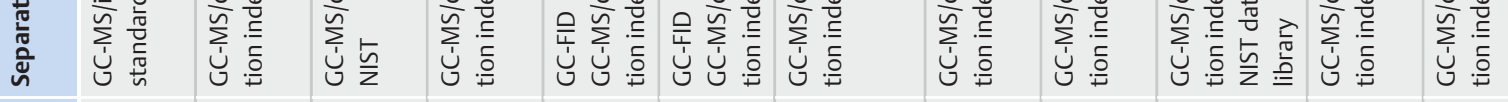

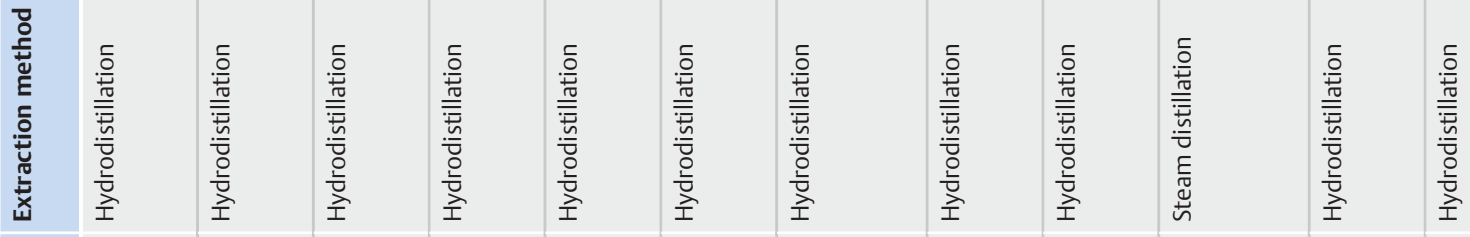

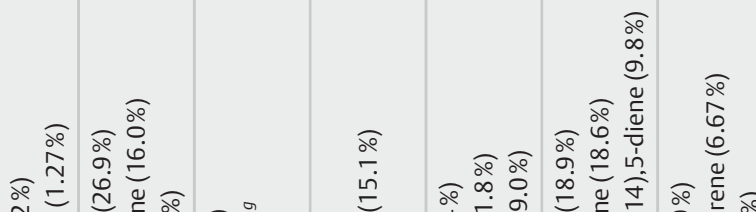

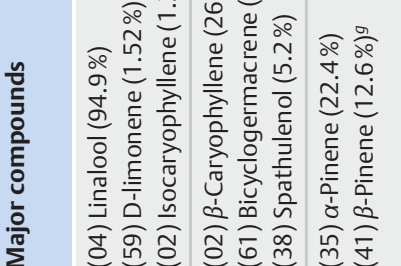

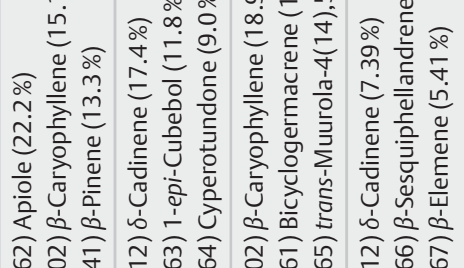

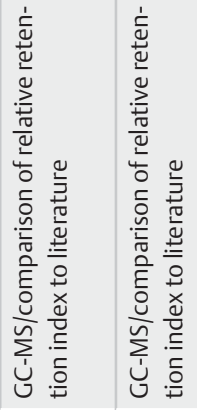

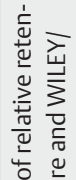

离 离

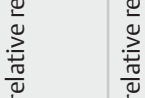

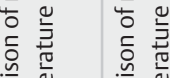

鱼贾

至要

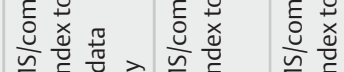




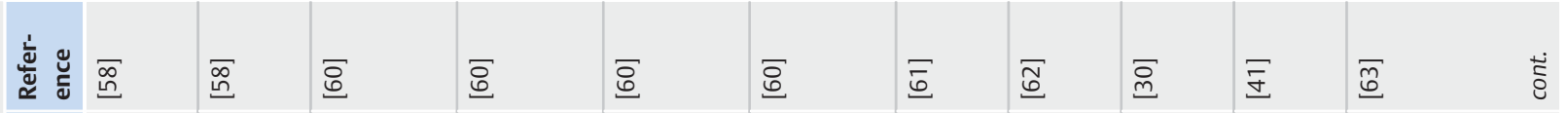

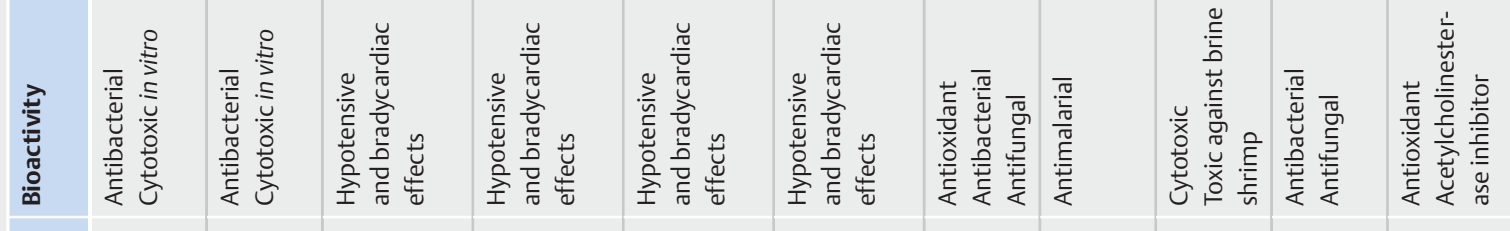

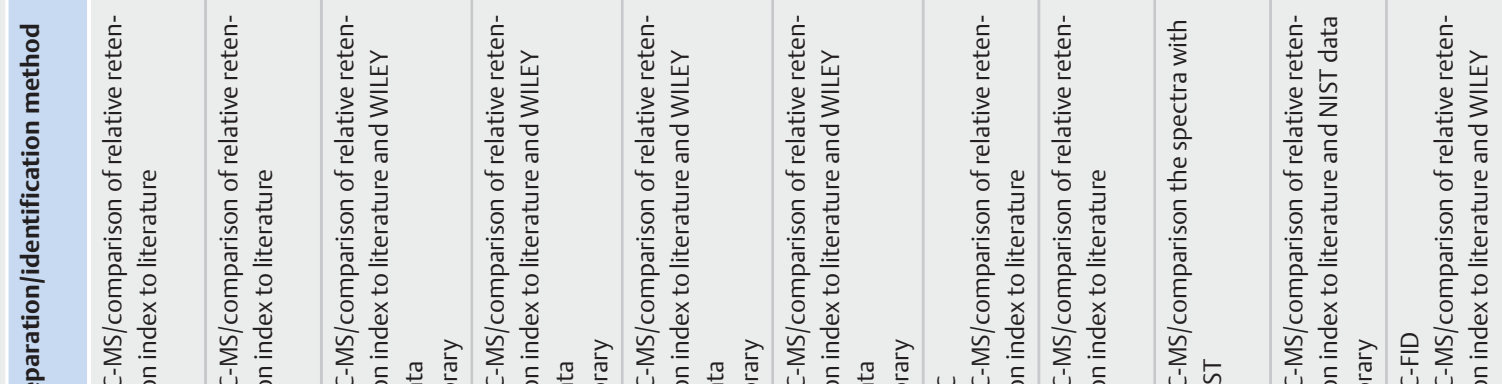

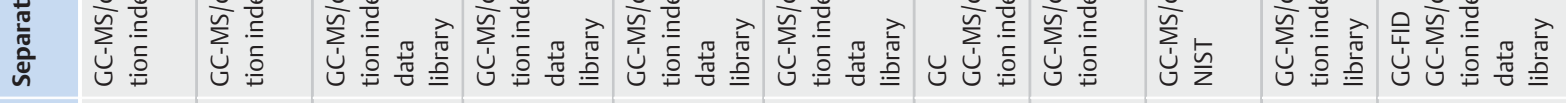

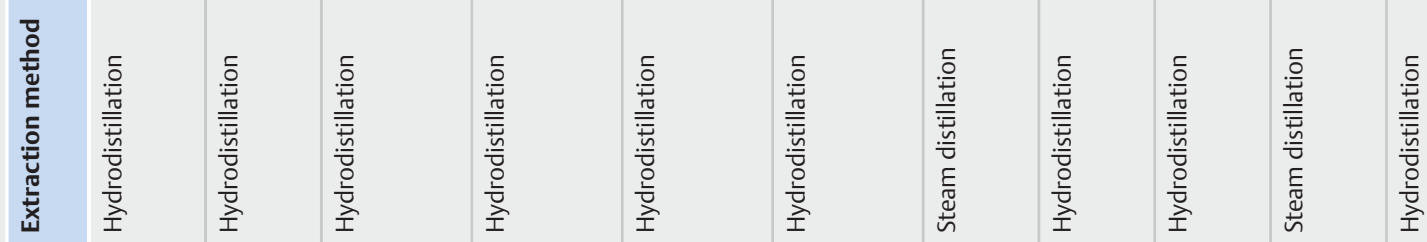

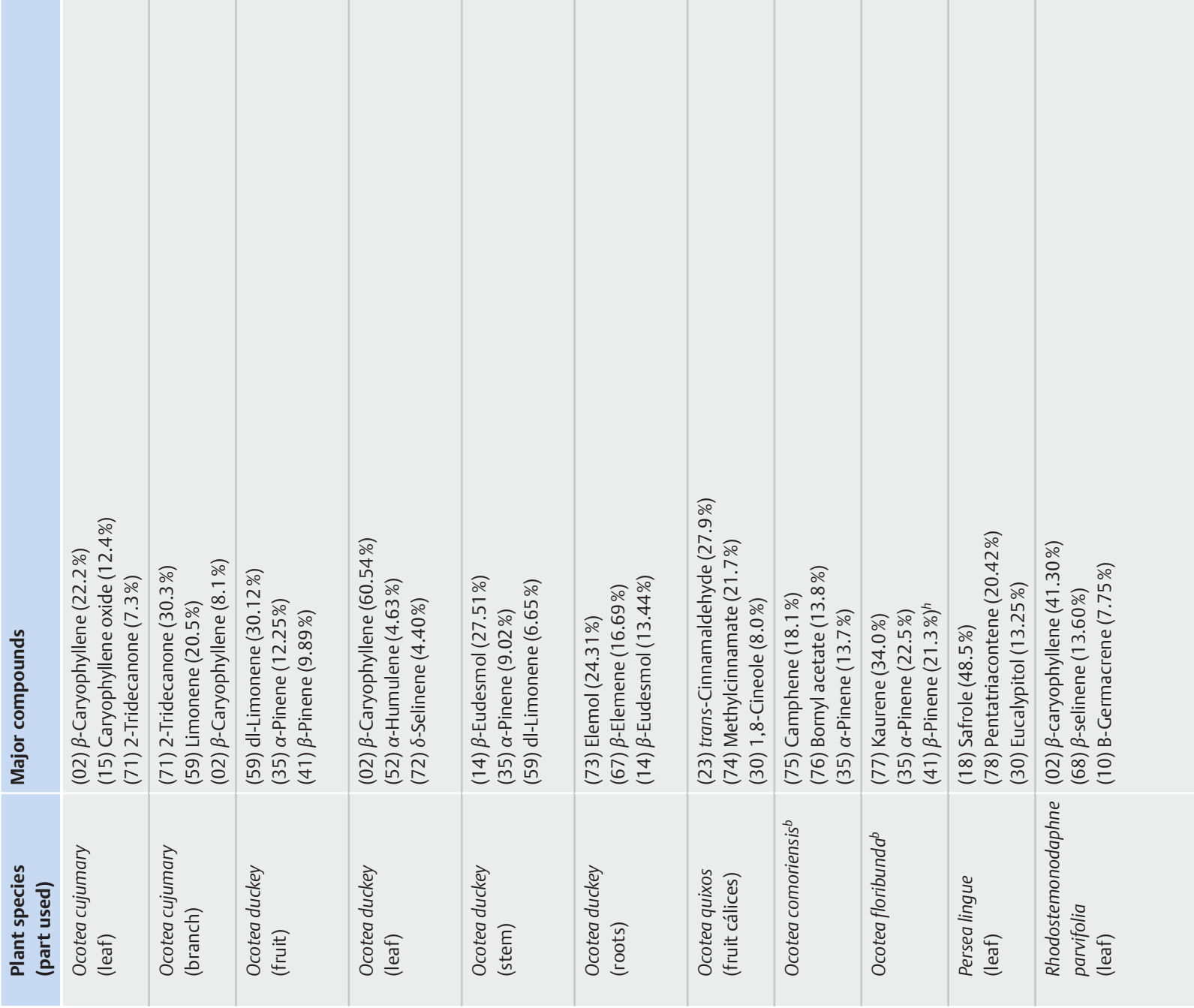




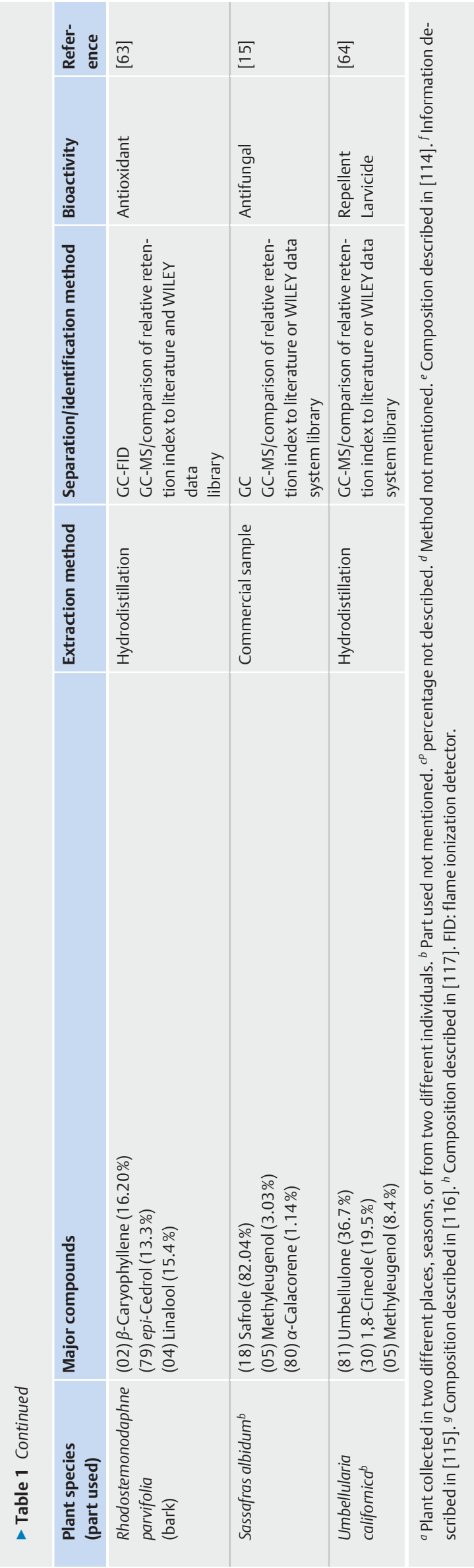

substance $\delta$-cadinene, its reported activities include antitumoral [79], antimicrobial [80], and acaricide [81]. Sesquiterpene $\delta$-cadinene has a cadinan skeleton originating from the cyclization of nerolidine pyrophosphate, which has farnesyl pyrophosphate as a precursor [82], and $\alpha$-pinene is a bicyclic monoterpene with many documented activities due to its anti-inflammatory $[83,84]$ and antiulcerogenic [85] properties.

It is important to note that there is a close relationship between the chirality of organic compounds and their biological activity. The activity is not identical in both enantiomers of an optically active substance. Linalool, for example, is a racemic mixture of two enantiomers, (3S)-(+)-linalool (coryandrol) and (3R)$(-)$-linalool (licareol), both of which have distinct properties [86, 87]. The anesthetic property of $(S)-(+)$ - and $(R)-(-)$-linalool has been tested on silver catfish (Rhamdia quelen), showing that $(R)$ (-)-linalol demonstrated clear advantages at a lower concentration [88]. Regarding anticonvulsant activity, de Sousa et al. [89] demonstrated that $(R)-(-)$-linalool and the racemate form were more active than the $(S)-(+)$ enantiomer, which had effects compatible with known anticonvulsant agents (diazepam, phenytoin). In a review presented by Aprotosoaie et al. [86], it was shown that although $(S)-(+)-$ and $(R)-(-)$-linalool have similar activity profiles, the effects of $(R)-(-)$ - linalool is more intense.

\section{Antioxidant activity}

The human organism is subjected to oxidative stress caused by oxygen reactive (ORS) and nitrogen reactive species. These species might be endogenous, generated through the cell's own metabolism and aerobic processes, or exogenous, from the environment [90-92]. Thus, an excess of ORS in the organism triggers deleterious effects on the cell membrane, proteins, carbohydrates, DNA, and RNA. Reactive species are also related to degenerative diseases such as cancer, cardiopathies, and atherosclerosis [93, 94].

In normal physiological conditions, ORS production is balanced by an efficient antioxidant system, formed by molecules capable of removing the reactive species and preventing cell damage [95]. According to Halliwell [92], antioxidants comprise substances that, in low concentrations, significantly delay or inhibit the oxidation of the substrate. Antioxidant compounds from fruits, vegetables, and herbs have been extensively studied, among which, vitamins ( $\alpha$-tocopherol, $\beta$-carotene, and ascorbic acid), carotenoids, flavonoids, other polyphenols, furanoids, thiols, and EOs stand out [96]. The antioxidant properties of EOs have been studied in a number of in vitro assays, with such activity being conferred mainly by the presence of terpenoids and phenolic compounds [11].

Studies performed with EO extracted from Rhodostemonodaphne parvifolia Madriñán showed its free radical scavenging activity in chromatography plates. However, a quantitative assay [antioxidant activity against 2,2-diphenyl-1-picrylhydrazyl (DPPH)] demonstrated activity only above $1000 \mathrm{mg} / \mathrm{mL}$ [63].

Bruni and collaborators [61] demonstrated that the EO from fruit calyces of Ocotea quixos (Lam.) Kosterm reduced $52 \%$ of the DPPH radical. On the other hand, results from the inhibition of linoleic acid oxidation through the $\beta$-carotene/linoleic acid assay were not expressive. This reveals different EO behavior in free 
- Table 2 Structures of the major chemical constituents from the listed Lauraceae species in the studies selected through this systematic review.

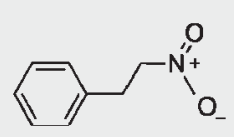

(01) 1-Nitro-2-phenylethane<smiles>C=Cc1ccc(OC)c(OC)c1</smiles>

(05) Methyleugenol

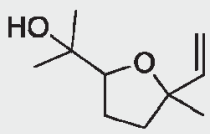

(09) trans-Linalool oxide

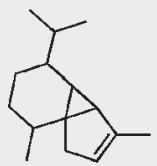

(13) $\alpha$-Cubebene<smiles>C=CCc1cc2c(cc1OC)OCO2</smiles><smiles>CC1=CCC2C3CCCC1C2(C)CC3C(C)C</smiles><smiles>COc1ccccc1/C=C/C(=O)O</smiles>

(25) cis-2-Methoxycinnamic acid

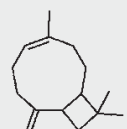

(02) $\beta$-Caryophyllene<smiles>C=CCc1ccc(O)c(OC)c1</smiles>

(06) Eugenol<smiles>C/C=C(\C)CCC1=CCCC(=C(C)C)CC1</smiles>

(10) Germacrene B<smiles>C=C1CCCC2(C)CCC(C(C)(C)O)CC12</smiles>

(14) $\beta$-Eudesmo

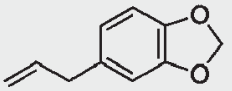

(18) Safrole<smiles>O=C/C=C/c1ccccc1O</smiles>

(22) 2-Hydroxy-cinnamaldehyde<smiles>COc1ccccc1/C=C/C=O</smiles>

(26) 2-Methoxy-cinnamaldehyde<smiles>C=C(C)C1CCC2(C)CCCC(C)(O)C2C1</smiles>

(03) Selin-11-en-4- $\alpha$-ol<smiles>CCC1CC(C)CC(C)C1</smiles>

(07) $\beta$-phellandrene

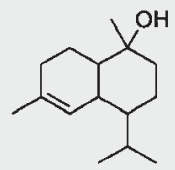

(11) $\alpha$-Cadinol<smiles>C=C1CCC2OC2CCC2C1CC2(C)C</smiles>

(15) Caryophyllene oxide<smiles>C=C(/C=C\C(CCC(C)=CCC)C(C)C)CC</smiles>

(19) Germacrene D<smiles>O=C/C=C/c1ccccc1</smiles>

(23) Cinnamaldehyde<smiles>O=CCCc1ccccc1</smiles>

(27) Hydrocinnamaldehyde

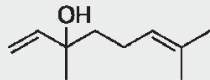

(04) Linalool<smiles>CC1=CCC(C(C)(C)O)CC1</smiles>

(08) $\alpha$-Terpineo<smiles>CC1=CC2C(=C(C)CCC2C(C)C)CC1</smiles>

(12) $\delta$-Cadinene<smiles>C=C1CCCC2(C)CCC3C(C)(C)CC132</smiles>

(16) $\beta$-Panasinsene<smiles>C=CCc1ccc(OC(C)=O)c(OC)c1</smiles>

(20) Eugenol acetate<smiles>O=c1ccc2ccccc2o1</smiles>

(24) Coumarin<smiles>OC/C=C/c1ccccc1</smiles>

(28) Cinnamyl alcoho 
- Table 2 Continued

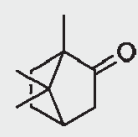

(29) Camphor<smiles>CC(C)=CC(=O)CC(C)c1ccc(C)cc1</smiles>

(33) Aromatic tumerone<smiles>C=CC(C=C(C)C)C(=C)C</smiles>

(37) Santolina triene<smiles>C=C1CCC2CC1C2(C)C</smiles>

(41) $\beta$-Pinene<smiles>CC(C)=CCC/C(C)=C/C(=O)O</smiles>

45) Geranic acid<smiles>CC1=CC=C(C(C)C)CC1</smiles>

(49) $\alpha$-Terpinene

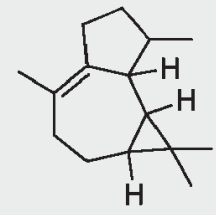

(53) Viridiflorene

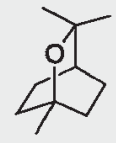

(30) 1,8-Cineole

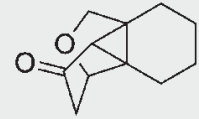

(34) 11-Oxatetracyclo[5.3.2.0(2,7).

$0(2,8)$ ]dodecan-9-one

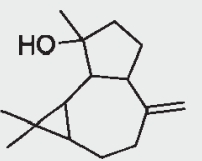

(38) Spathuleno<smiles>Cc1ccc(C(C)C)cc1</smiles>

(42) $\alpha$-Phellandrene

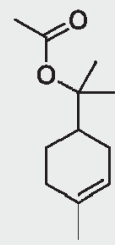

(46) $\alpha$-Terpinyl-acetate

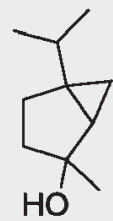

(50) trans-Sabinene hydrate

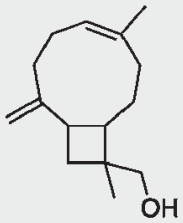

(54) 14-Hydroxy-9-epi-B-

caryophyllene<smiles>CCC(C)CCC(C)C</smiles><smiles>O=C/C=C\c1ccccc1</smiles>

(32) cis-Cinnamaldehyde

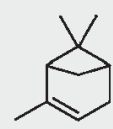

(35) $\alpha$-Pinene<smiles>CC(=O)OC/C=C/c1ccccc1</smiles>

(39) Cinnamyl-acetate<smiles>C=C1CC=C(C(C)C)CC1</smiles>

(43) $\beta$-Terpinene

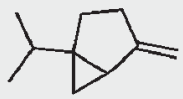

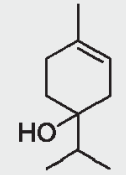

(36) Terpinen-4-ol<smiles>O=C(OCc1ccccc1)c1ccccc1</smiles>

(40) Ascabin

(44) Methyl geranate
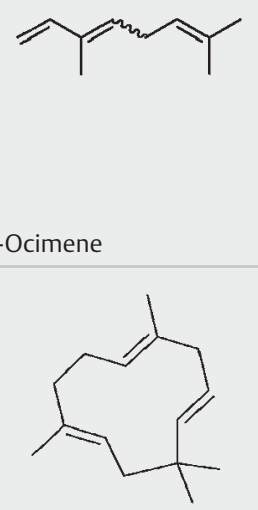

52) $\alpha$-Humulene

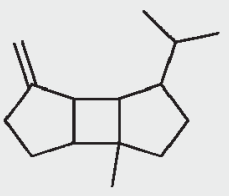


- Table 2 Continued

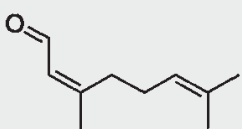

(57) Z-Citra<smiles>CC1=CC2C(=CCC1)CCC1C2C1(C)C</smiles>

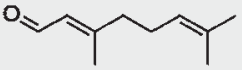

(58) E-Citra

(59) Limonene<smiles></smiles>

(63) 1-epi-Cubebol

(66) $\beta$-Sesquiphellandrene

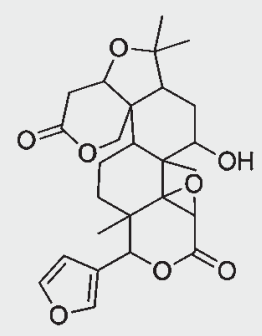

(60) Limonol<smiles>CC1=C2CC3CC(C)(C4CC(=O)C1C34C)C2(C)C</smiles>

(64) Cyperotundone<smiles>C=C(C)C1CCC2CCCC(=C)C2C1</smiles>

(68) $\beta$-Selinene<smiles>CC1=C2C=C(C(C)C)CCC2(C)CCC1</smiles>

(72) $\delta$-Selinene<smiles>CC(=O)OC1(C)C2CCC1(C)CC2</smiles>

(76) Bornylacetate

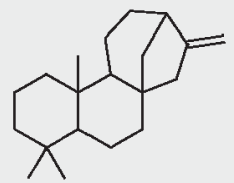

(77) Kaurene

(79) epi-Cedrol<smiles>C=C(C)C1CCC2(C)CCC=C(C)C2C1</smiles>

(69) 7-epi-a-Selinene<smiles>C=CC1(C)CCC(C(C)(C)O)CC1C(=C)C</smiles>

(73) Elemol

(74) Methyl cinnamate

(75) Camphene<smiles>C=C1C=CC(C(C)CCC=C(C)C)CC1</smiles><smiles>CC1=CC2C(C(C)C)CCC(C)(O)C2CC1</smiles>

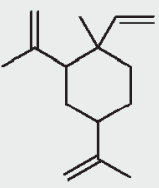

(67) $\beta$-Elemene

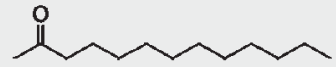

(71) 2-Tridecanone<smiles>COC(=O)CCc1ccccc1</smiles>

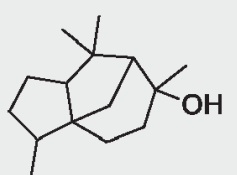

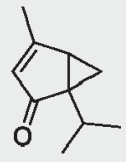

(81) Umbellulone radical reduction and in the inhibition of oxidation, suggesting that polar components from EOs might be responsible for the activities in the DPPH assay.

Studies performed using the Beilschmiedia genus revealed antioxidant activity in Beilschmiedia madang Blume, Beilschmiedia kunstleri, Beilschmiedia maingayi, Beilschmiedia penangiana, and
Beilschmiedia pulverulenta $[16,17]$. From the evaluated species, $B$. maingayi showed the best results with an $\mathrm{IC}_{50 \%} \mathrm{~s}$ of $84.7 \mu \mathrm{g} \cdot \mathrm{mL}^{-1}$ and $108.3 \mu \mathrm{g} \cdot \mathrm{mL}^{-1}$ in the DPPH and ABTS assays, respectively. The species also exhibited $125.9 \%$ inhibition in the $\beta$-carotene/linoleic acid assay and total phenolic content of $288.2 \mathrm{mg} \mathrm{GA} \cdot \mathrm{g}^{-1}[16,17]$. 


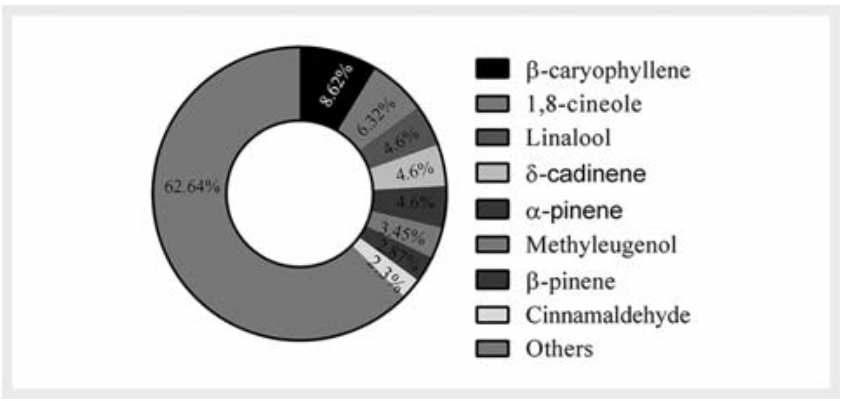

- Fig. 2 Chemical constituents most found in the listed Lauraceae species.

\section{Antibacterial activity}

Medicinal plants are a viable therapeutic option to use against microorganisms that are resistant to antibiotics. The products of the secondary metabolisms of plants can operate in two ways. The first consists of boosting the antibacterial activity, favoring the activity of antibiotics with limited action due to bacterial resistance and, consequently, minimizing toxicity. The second involves the improvement of the response of the immune system to infection, thus the products can act as virulence extenuating agents $[97,98]$.

Among the mechanisms by which EOs present antibacterial activity, one may cite their interference in the phospholipid double layer from the bacterial cell wall, an increase in the permeability and loss of cell constituents, and the alteration of the enzymatic systems involved in energy and the production of structural components or destruction of genetic material [99]. Bacteriostatic and/or bactericidal activities of EOs are exerted mainly by oxygenated terpene compounds (e.g., alcohols and phenolic terpenes), however, some hydrocarbons also have antibacterial effects $[100,101]$.

Researches using Beilschmiedia genus demonstrated antibacterial activity of EO extracted from the leaves and barks of $B$. madang Blume, B. kunstleri, B. maingayi, B. penangiana [16], and B. pulverulenta [19]. EO from Laurus nobilis has also been reported as a good antibacterial agent [43-46].

\section{Antifungal activity}

The treatment of diseases caused by fungi is limited due to the difficulties inherent in a diagnosis. Available antifungal drugs have expressive toxicity and can cause both resistance and infection recurrence. Thus, the search for antifungals originating from plants might enable the development of innovative medicines [102, 103]. EOs present some degree of antifungal activity and may act as fungistatic and/or fungicide agents, depending on their concentration [104]. This activity has been attributed to a range of substances, including phenolic compounds, monoterpenes, and terpenoids [105]. Considering the number of chemically distinct compounds in EOs, it is highly probable that the antifungal activity involves different mechanisms of action, which are, in part, linked to hydrophobicity $[99,100]$.

These mechanisms are not yet well elucidated; nonetheless, studies indicate that most EOs are capable of interacting with lip- idic structures and causing modifications to the cell wall of the pathogen, leading to increased permeability of the cytoplasmic membrane and damaging the processes essential to cell survival [106]. The inactivation of certain enzymes, including those involved in energy production and the synthesis of structural components, is one possible such mechanism [107].

The antifungal activity of EO extracted from Cinnamomum species is extensively reported in the literature. An essential oil from Cinnamomum cássia inhibited strains of Aspergillus flavus and Aspergillus oryzae at $125 \mathrm{ppm}$ and $250 \mathrm{ppm}$, respectively [22], four species of Candida (Candida albicans, Candida tropicalis, Candida glabrata, and Candida Krusei), and filamentous and dermatophyte fungi [24]. Cinnamomum zeylanicum showed activity against Phomopsis helianthi, Cladosporium fulvium and Cladosporium cladosporioide [15]. Of the tested fungal species, Trichoderma viride presented the greatest resistance to the oil [15].

\section{Anti-inflammatory activity}

The inflammatory reaction is a physiopathological response of the host against aggressive stimuli, e.g., pathogenic and irritant agents or damaged cells. The reaction is classified as acute or chronic, and involves a cascade of biochemical events [108,109]. In inflammatory responses, there is an increase in permeability of the endothelial coating and thus a higher influx of leukocytes from the blood stream to the interstice. Intense oxidative processes and the release of cytokines (interleukins and TNF- $\alpha$ ) also occur. At the same time, there is an induction of activity in many enzymes (oxygenases, nitric oxide synthase, peroxidases), together with the arachidonic acid metabolism. The expression of adhesion molecules, such as intercellular adhesion molecules (ICAM) and vascular cell adhesion molecules, also participates in this process [110]. The anti-inflammatory activity of EOs may be related to its antioxidant activity, and to its interaction in signaling cascades involving cytokines, the regulation of transcription factors, and the expression of proinflammatory genes [111].

In addition to other activities, the Beilschmiedia genus demonstrated anti-inflammatory potential for B. kunstleri, B. maingayi, and $B$. penangiana through the lipoxygenase (LOX) assay. From these species, EO from the leaves and bark of $B$. maingayi exhibited the best results, with inhibitions of 77.0 and $73.5 \%$, respectively. This activity was attributed to the presence of $\beta$-caryophyllene, limonene, and caryophyllene oxide, which are known to be LOX inhibitors [16].

Another study using the EO extracted from the leaves of Cinnamomum osmophloeum $(60 \mu \mathrm{g} / \mathrm{mL})$ in mice showed a high capability for inhibiting the expression of prolL- $1 \beta$ in macrophages activated by lipopolysaccharides (LPS). Furthermore, at $60 \mu \mathrm{g} / \mathrm{mL}$, the EO was efficient at inhibiting IL- $1 \beta$ and IL- 6 but not TNF- $\alpha$, suggesting that the EO presented in vitro activity [28].

\section{Toxic activity}

Among the preliminary evaluations for the toxicity of EOs and extracts derived from plants is the assay against Artemia salina [112]. EO from the bark of Aniba canelilla was evaluated by Da Silva et al. [13], who compared the activity of the EO with one of its isolated major compounds (1-nitro-2-phenylethane). From the assays performed, toxic activity was observed in both samples, with a low 
$\mathrm{IC}_{50} \mathrm{~s}$ of $21.61 \mu \mathrm{g} / \mathrm{mL}$ for the EO and $20.37 \mu \mathrm{g} / \mathrm{mL}$ for 1 -nitro-2phenylethane. Silva and collaborators [14] undertook a complementary evaluation of the toxicity of EO from the leaves of A. canelilla according to the same method, however, the $\mathrm{IC}_{50}$ obtained here was $68.37 \mu \mathrm{g} / \mathrm{mL}$, approximately three times higher than the EO of the bark. It is important to note that, although 1nitro-2-phenylethane was found as a major compound and with similar percentages in both EOs, the biological activity of samples obtained from natural products occurs through synergism between all substances present. Nevertheless, both samples can be considered very toxic [112].

EOs from four other Lauraceae species were also evaluated: $\mathrm{Li}$ caria canella [14], Cinnamomum tonduzii, Nectandra membranacea, and Ocotea floribunda [30]. All samples presented an $\mathrm{IC}_{50}$ lower than $40 \mu \mathrm{g} / \mathrm{mL}$. The EOs of leaves of $N$. membranaceae and O. floribunda presented a lethal concentration $50 \%$ below $5 \mu \mathrm{g} / \mathrm{mL}$ (IC $50=3.7 \mu \mathrm{g} / \mathrm{mL}$ for both) [30].

The toxicity of the EO from O. floribunda was also tested in cell lines through the tetrazolium reduction method (MTT). This assay evaluates cell viability [113], and the sample analyzed caused the death of around $78 \%$ of human hepatocarcinoma cells (Hep G2) at $100 \mathrm{mg} / \mathrm{mL}$ [30]. On the other hand, the EO of leaves and stems from Endlicheria citriodora, when evaluated through the Alamar Blue assay in three cell lines (murine fibroblast and melanoma, and gastric adenocarcinoma) showed low toxicity, since at $50 \mu \mathrm{g} /$ $\mathrm{mL}$, the samples did not cause the death of $50 \%$ of the cells [42].

The toxic potential or absence of toxicity determines the uses and applications of the EOs. An example of this situation is the EO from the leaves of $A$. canelilla and $L$. canella. The samples presented moderate activity against Leishmania amazonensis; later on, both EOs were studied with regard to the toxicity in noninfected macrophages [14]. For both samples, low toxicity was observed [14]. This is considered promising, since it implies that the EO has the potential to treat leishmaniasis without causing problems to the patient.

\section{Conclusion}

The present review concludes that the Lauraceae family includes several species that produce essential oils, with chemical compositions predominated by sesquiterpene $\beta$-caryophyllene and monoterpene 1,8 cineol. Both of these compounds have several biological and pharmacological potentials, which have been proven in previous literature.

Among the activities of the essential oils of the species presented in the reviewed studies, we highlight (i) the antioxidant property evidenced by means of different chromatography techniques, (ii) their antimicrobial activity, wherein several strains of microorganisms were inhibited, (iii) their anti-inflammatory potential, and (iv) their toxic activity. Thus, according to the chemical composition and activity of the essential oils, their use can be directed towards the cosmetic, food, or pharmaceutical industry for diverse applications.

\section{Acknowledgements}

The authors extend their appreciation to the PhD Program in Pharmaceutical Sciences of the Federal University of Parana, Brazil.

\section{Conflict of Interest}

The authors declare no conflict of interest.

\section{References}

[1] Souza VC, Lorenzi H. Botânica sistemática: guia ilustrado para identificação das famílias de Angiospermas da Flora brasileira, baseado em APG II. Instituto Plantarum: Nova Odessa; 2005: 640

[2] APG IV (Angiosperm Phylogeny Group IV). An update of the Angiosperm Phylogeny Group classification for the orders and families of flowering plants: APG IV. Bot J Linn Soc 2016; 181: 1-20

[3] Salleh WMNHW, Ahmad F, Yen KH, Zulkifli RM. A review on chemical constituents and biological activities of the genus Beilschmiedia (Lauraceae). Trop J Pharm Res 2015; 14: 2139-2150

[4] Li Y, Xie S, Ying J, Wei W, Gao K. Chemical structures of lignans and neolignans isolated from Lauraceae. Molecules 2018; 23: E3164

[5] Desgagné-Penix I. Distribution of alkaloids in woody plants. Plant Sci Today 2017; 4: 137-142

[6] Chaverri C, Cicció JF. Volatile constituents of the oils from Povedadaphne quadriporata(Lauraceae) from "Alberto M. Brenes" biological preserve, Costa Rica. Quím Nova 2008; 31: 605-609

[7] Smith RL, Cohen SM, Doull J, Feron VJ, Goodman Jl, Marnett LJ, Portoghese OS, Waddell WJ, Wagner BM, Hall RL, Higley NA, Lucas-Gavin C, Adams TB. A procedure for the safety evaluation of natural flavor complexes used as ingredients in food: essential oils. Food Chem Toxicol 2005; 43: 345-363

[8] Dorman HJD, Deans SG. Antimicrobial agents from plants: antibacteria activity of plant volatile oils. J Appl Microbiol 2000; 88: 308-316

[9] Matos SP, Teixeira HF, de Lima ÁA, Veiga-Junio VF, Koester LS. Essentia Oils and Isolated Terpenes in Nanosystems Designed for Topical Administration: A Review. Biomolecules 2019; 9: E138

[10] Dewick PM. The biosynthesis of C5-C25 terpenoid compounds. Nat Prod Rep 2002; 19: 181-222

[11] Bakkali F, Averbeck S, Averbeck D, Idaomar M. Biological effects of essential oils-a review. Food Chem Toxicol 2008; 46: 446-475

[12] Salleh WMNHW, Ahmad F, Yen KH, Zulkifli RM. Essential oil compositions of Malaysian Lauraceae: a mini review. Pharm Sci 2016; 22: 60-67

[13] da Silva JK, Sousa PJC, Andrade EHA, Maia JGS. Antioxidant capacity and cytotoxicity of essential oil and methanol extract of Aniba canelilla (HBK) Mez. J Sci Food Agric 2007; 55: 9422-9426

[14] Silva JRDA, do Carmo DF, Reis ÉM, Machado G, Leon LL, da Silva BOD, Ferreira JLP, Amaral ACF. Chemical and biological evaluation of essential oils with economic value from Lauraceae species. J Braz Chem Soc 2009; 20: 1071-1076

[15] Simić A, Soković MD, Ristić M, Grujić-Jovanović S, Vukojević ], Marin PD. The chemical composition of some Lauraceae essential oils and their antifungal activities. Phytother Res 2004; 18: 713-717

[16] Salleh WMNHW, Ahmad F, Khong HY, Mohamed Zulkifli R. Comparative study of the essential oils of three Beilschmiedia species and their biological activities. Int J Food Sci Tech 2016; 51: 240-249 a

[17] Salleh WM, Ahmad F, Yen KH. Chemical compositions and biological activities of the essential oils of Beilschmiedia madang Blume (Lauraceae). Arch Pharm Res 2015; 38: 485-493 
[18] Carvajal MA, Vergara AP, Santander R, Osorio ME. Chemical composition and anti-phytopathogenic activity of the essential oil of Beilschmiedia miersii. Nat Prod Commun 2016; 11: 1367-1372

[19] Salleh WM, Ahmad F, Yen KH, Zulkifli RM. Chemical composition and biological activities of essential oil of Beilschmiedia pulverulenta. Pharm Biol 2016; 54: 322-330 b

[20] Choi J, Lee KT, Ka H, Jung WT, Jung HJ, Park H]. Constituents of the essential oil of the Cinnamomum cassia stem bark and the biological properties. Arch Pharm Res 2001; 24: 418-423

[21] Chou ST, Chang WL, Chang CT, Hsu SL, Lin YC, Shih Y. Cinnamomum cassia essential oil inhibits $\alpha$-MSH-induced melanin production and oxidative stress in murine B16 melanoma cells. Int J Mol Sci 2013; 14: 19186-19201

[22] Kocevski D, Du M, Kan J, Jing C, Lačanin I, Pavlović H. Antifungal effect of Allium tuberosum, Cinnamomum cassia, and Pogostemon cablin essential oils and their components against population of Aspergillus species. J Food Sci 2013; 78: 731-737

[23] Jiang H, Wang J, Song L, Cao X, Yao X, Tang F, Yue Y. GCXGC-TOFMS analysis of essential oils composition from leaves, twigs and seeds of Cinnamomum camphora $\mathrm{L}$. Presl and their insecticidal and repellent activities. Molecules 2016; 21: 423

[24] Ooi LS, Li Y, Kam SL, Wang H, Wong EY, Ooi VE. Antimicrobial activities of cinnamon oil and cinnamaldehyde from the Chinese medicinal herb Cinnamomum cassia Blume. Am J Chin Med 2006; 34: 511-522

[25] Sun L, Zong SB, Li JC, Lv YZ, Liu LN, Wang ZZ, Zhou J, Cao L, Kou JP, Xiao W. The essential oil from the twigs of Cinnamomum cassia Presl alleviates pain and inflammation in mice. J Ethnopharmacol 2016; 194: 904-912

[26] Singh C, Singh S, Pande C, Tewari G, Pande V, Sharma P. Exploration of antimicrobial potential of essential oils of Cinnamomum glanduliferum, Feronia elephantum, Bupleurum hamiltonii and Cyclospermum leptophyllum against foodborne pathogens. Pharm Biol 2013; 51: 1607-1610

[27] Taha AM, Eldahshan OA. Chemical characteristics, antimicrobial, and cytotoxic activities of the essential oil of Egyptian Cinnamomum glanduliferum bark. Chem Biodivers 2017; 14: e1600443

[28] Chao LK, Hua KF, Hsu HY, Cheng SS, Liu JY, Chang ST. Study on the antiinflammatory activity of essential oil from leaves of Cinnamomum osmophloeum. J Agric Food Chem 2005; 53: 7274-7278

[29] Kumar S, Vasudeva N, Sharma S. GC-MS analysis and screening of antidiabetic, antioxidant and hypolipidemic potential of Cinnamomum tamala oil in streptozotocin induced diabetes mellitus in rats. Cardiovasc Diabetol 2012; 11: 95

[30] Werka JS, Boehme AK, Setzer WN. Biological activities of essential oils from Monteverde, Costa Rica. Nat Prod Commun 2007; 2: 1215-1219

[31] Naveed R, Hussain I, Tawab A, Tariq M, Rahman M, Hameed S, Mahmood MS, Siddique AB, Iqbal M. Antimicrobial activity of the bioactive components of essential oils from Pakistani spices against Salmonella and other multi-drug resistant bacteria. BMC Complement Altern Med 2013; 13 : 265

[32] Smith-Palmer A, Stewart J, Fyfe L. Inhibition of listeriolysin O and phosphatidylcholine-specific production in Listeria monocytogenes by subinhibitory concentrations of plant essential oils. J Med Microbiol 2002; 51: 567-608

[33] Azeredo CM, Santos TG, Maia BH, Soares M]. In vitro biological evaluation of eight different essential oils against Trypanosoma cruzi, with emphasis on Cinnamomum verum essential oil. BMC Complement Altern Med 2014; 14: 309

[34] Monteiro IN, Monteiro SO, Costa-Junior LM, Lima SA, Andrade AEH, Maia JGS, Mouchrek Filho VE. Chemical composition and acaricide activity of an essential oil from a rare chemotype of Cinnamomum verum Presl on Rhipicephalus microplus (Acari: Ixodidae). Vet Parasitol 2017; 238: 54-57

[35] Deletre E, Chandre F, Williams L, Duménil C, Menut C, Martin T. Electrophysiological and behavioral characterization of bioactive compounds of the Thymus vulgaris, Cymbopogon winterianus, Cuminum cym- inum and Cinnamomum zeylanicum essential oils against Anopheles gambiae and prospects for their use as bednet treatments. Parasit Vectors 2015; 8: 316

[36] Trajano VN, Lima EDO, Travassos AE, Souza ELD. Inhibitory effect of the essential oil from Cinnamomum zeylanicum Blume leaves on some foodrelated bacteria. Food Sci Technol 2010; 30: 771-775

[37] Han X, Parker TL. Antiinflammatory activity of cinnamon (Cinnamomum zeylanicum) bark essential oil in a human skin disease model. Phytother Res 2017; 31: 1034-1038

[38] Ben-Fadhel Y, Saltaji S, Khlifi MA, Salmieri S, Vu KD, Lacroix M. Active edible coating and $\gamma$-irradiation as cold combined treatments to assure the safety of broccoli florets (Brassica oleracea L.). Int J Food Microbiol 2017; 241: 30-38

[39] Bartoňková I, Dvořák Z. Essential oils of culinary herbs and spices display agonist and antagonist activities at human aryl hydrocarbon receptor AhR. Food Chem Toxicol 2018; 111: 374-384

[40] Brnawi WI, Hettiarachchy NS, Horax R, Kumar-Phillips G, Seo HS, Marcy ]. Comparison of cinnamon essential oils from leaf and bark with respect to antimicrobial activity and sensory acceptability in strawberry shake. J Food Sci 2018; 83: 475-480

[41] Lorca MA, Canales CL, Valenzuela CG, Concha EB, Chait AB, Navarrete EP, Berner MB. Efectos antimicrobianos de extractos de plantas chilenas de las familias Lauraceae y Atherospermataceae. Rev Cuba Plantas Med 2012; 17: 73-83

[42] Yamaguchi KK, Veiga-Junior VF, Pedrosa TN, Vasconcellos MC, Lima ES. Atividades biológicas dos óleos essenciais de Endlicheria citriodora, uma Lauraceae rica em geranato de metila. Quim Nova 2013; 36: 826-830

[43] Marzouki H, Khaldi A, Chamli R, Bouzid S, Piras A, Falconieri D, Marongiu B. Biological activity evaluation of the oils from Laurus nobilis of Tunisia and Algeria extracted by supercritical carbon dioxide. Nat Prod Res 2009; 23: $230-237$

[44] Ozcan B, Esen M, Sangun MK, Coleri A, Caliskan M. Effective antibacteria and antioxidant properties of methanolic extract of Laurus nobilis seed oil. J Environ Biol 2010; 31: 637-641

[45] Ramos C, Teixeira B, Batista I, Matos O, Serrano C, Neng NR, Nogueira JMF, Nunes ML, Marques A. Antioxidant and antibacterial activity of essential oil and extracts of bay laurel Laurus nobilis Linnaeus (Lauraceae) from Portugal. Nat Prod Res 2012; 26: 518-529

[46] Dadalioglu I, Evrendilek GA. Chemical compositions and antibacterial effects of essential oils of Turkish oregano (Origanum minutiflorum), bay laurel (Laurus nobilis), Spanish lavender (Lavandula stoechas L.), and fennel (Foeniculum vulgare) on common foodborne pathogens. J Agric Food Chem 2004; 52: 8255-8260

[47] Saab AM, Tundis R, Loizzo MR, Lampronti I, Borgatti M, Gambari R, Menichini F, Esseily F, Menichini F. Antioxidant and antiproliferative activity of Laurus nobilis L. (Lauraceae) leaves and seeds essential oils against K562 human chronic myelogenous leukaemia cells. Nat Prod Res 2012; 26: $1741-1745$

[48] Caputo L, Nazzaro F, Souza LF, Aliberti L, De Martino L, Fratianni F, Coppola R, De Feo V. Laurus nobilis: Composition of essential oil and its biological activities. Molecules 2017; 22: E930

[49] Da Silva JK, Gomes M, Dosoky N, Maia JG, Setzer W. Chemical composition and in vitro biological activities of essential oil chemotypes of Licaria rigida (Kosterm.) Kosterm.(Lauraceae). Int J Appl Res Nat Prod 2016; 9: $1-9$

[50] Comai S, Dall'Acqua S, Grillo A, Castagliuolo I, Gurung K, Innocenti G. Essential oil of Lindera neesiana fruit: chemical analysis and its potential use in topical applications. Fitoterapia 2010; 81: 11-16

[51] Liu TT, Yang TS. Antimicrobial impact of the components of essential oil of Litsea cubeba from Taiwan and antimicrobial activity of the oil in food systems. Int J Food Microbiol 2012; 156: 68-75 
[52] Vongsombath C, Pålsson K, Björk L, Borg-Karlson AK, Jaenson TG. Mosquito (Diptera: Culicidae) repellency field tests of essential oils from plants traditionally used in Laos. J Med Entomol 2014; 49: 1398-1404

[53] Yang Y, Jiang J, Qimei L, Yan X, Zhao J, Yuan H, Qin Z, Wang M. The fungicidal terpenoids and essential oil from Litsea cubeba in Tibet. Molecules 2010; 15: 7075-7082

[54] Nguyen HV, Caruso D, Lebrun M, Nguyen NT, Trinh TT, Meile JC, Son SK, Sarter S. Antibacterial activity of Litsea cubeba (Lauraceae, May Chang) and its effects on the biological response of common carp Cyprinus carpio challenged with Aeromonas hydrophila. J Appl Microbiol 2016; 121: 341-351

[55] Da Silva JKR, Andrade EHA, Mourao RHV, Maia JGS, Dosoky NS, Setzer WN. Chemical profile and in vitro biological activities of essential oils of Nectandra puberula and N. cuspidata from the Amazon. Nat Prod Commun 2017; 12: 131-134

[56] Jani NA, Sirat HM, Ahmad F, Mohamad ANA, Jamil M. Chemical profiling and biological properties of Neolitsea kedahense Gamble essential oils. Nat Prod Res 2017; 31: 2793-2796

[57] Damasceno CSB, Oliveira LFD, Szabo EM, Souza ÂM, Dias JFG, Miguel MD, Miguel OG. Chemical composition, antioxidant and biological activity of Ocotea bicolor Vattimo-Gil (LAURACEAE) essential oil. Braz J Pharm Sci 2017; 53: e17298

[58] da Silva JK, da Trindade R, Moreira E, Maia J, Dosoky N, Miller R, Cseke L], Setzer W. Chemical diversity, biological activity, and genetic aspects of three Ocotea species from the Amazon. Int J Mol Sci 2017; 18: 1081

[59] Gil E, Cuca LE, Delgado WA. Chemical composition and antimicrobial activity of the essential o il of the leaves of Ocotea caudata (Nees) Mez (Lauraceae) from Colombia. B Latinoam Caribe PI 2016; 15: 258-263

[60] Barbosa-Filho JM, Cunha RM, Dias CS, Athayde-Filho PF, Silva MS, DaCunha EVL, Machado MIL, Craveiro AA, Medeiros IA. GC-MS analysis and cardiovascular activity of the essential oil of Ocotea duckei. Rev Bras Farmacogn 2008; 18: 37-41

[61] Bruni R, Medici A, Andreotti E, Fantin C, Muzzoli M, Dehesa M, Romagnoli C, Sacchetti G. Chemical composition and biological activities of Ishpingo essential oil, a traditional Ecuadorian spice from Ocoted quixos (Lam.) Kosterm. (Lauraceae) flower calices. Food Chem 2004; 85: 415-421

[62] Menut C, Bessiere JM, Said Hassani M, Buchbauer G, Schopper B. Chemical and biological studies of Ocotea comoriensis bark essential oil. Flavour Fragr | 2002; 17: 459-461

[63] Alcântara JM, Yamaguchi KDL, Silva JDA, Veiga-Junior VFD. Composição química e atividade biológica dos óleos essenciais das folhas e caules de Rhodostemonodaphne parvifolia Madriñán (Lauraceae). Acta Amaz 2010; 40: 567-572

[64] Tabanca N, Avonto C, Wang M, Parcher JF, Ali A, Demirci B, Raman V, Khan IA. Comparative investigation of Umbellularia californica and Laurus nobilis leaf essential oils and identification of constituents active against Aedes aegypti. J Agric Food Chem 2013; 61: 12283-12291

[65] Sköld M, Karlberg AT, Matura M, Börje A. The fragrance chemical $\beta$-caryophyllene - air oxidation and skin sensitization. Food Chem Toxicol 2006; 44: 538-545

[66] Fernandes ES, Passos GF, Medeiros R, da Cunha FM, Ferreira J, Campos MM, Pianowski LF, Calixto JB. Anti-inflammatory effects of compounds alpha-humulene and (-)-trans-caryophyllene isolated from the essential oil of Cordia verbenacea. Eur J Pharmacol 2007; 569: 228-236

[67] Viveros-Paredes J, González-Castañeda R, Gertsch J, Chaparro-Huerta V, López-Roa R, Vázquez-Valls E, Beas-Zarate C, Camins-Espuny A, FloresSoto M. Neuroprotective effects of $\beta$-caryophyllene against dopaminergic neuron injury in a murine model of parkinson's disease induced by MPTP. Pharmaceuticals 2017; 10: E60

[68] Dahham SS, Tabana YM, Iqbal MA, Ahamed MB, Ezzat MO, Majid AS, Majid AM. The anticancer, antioxidant and antimicrobial properties of the sesquiterpene $\beta$-caryophyllene from the essential oil of Aquilaria crassna. Molecules 2015; 20: 11808-11829
[69] Chavan M], Wakte PS, Shinde DB. Analgesic and anti-inflammatory activity of Caryophyllene oxide from Annona squamosa L. bark. Phytomedicine 2010; 17: 149-151

[70] Kehrl W, Sonnemann U, Dethlefsen U. Therapy for acute nonpurulent rhinosinusitis with cineole: results of a double-blind, randomized, placebo-controlled trial. Laryngoscope 2004; 114: 738-742

[71] Juergens UR, Dethlefsen U, Steinkamp G, Gillissen A, Repges R, Vetter H. Anti-inflammatory activity of 1.8-cineol (eucalyptol) in bronchial asthma: a double-blind placebo-controlled trial. Respir Med 2003; 97: 250256

[72] Juergens UR, Stober M, Schmidt-Schilling L, Kleuver T, Vetter H. Antiinflammatory effects of eucalyptol (1.8-cineole) in bronchial asthma: inhibition of arachidonic acid metabolism in human blood monocytes ex vivo. Eur J Med Res 1998; 3: 407-412

[73] Worth H, Schacher C, Dethlefsen U. Concomitant therapy with Cineole (Eeucalyptole) reduces exacerbations in COPD: a placebo-controlled double-blind trial. Respir Res 2009; 10: 69

[74] Nascimento RFN, Refosco RMC, Vasconcelos ECF, Kerntopf MR, Santos CF, Batista FJA, de Sousa CM, Fonteles MC. 1, 8-Cineole induces relaxation in rat and guinea-pig airway smooth muscle. J Pharm Pharmacol 2009; 61: 361-366

[75] Lapczynski A, Letizia CS, Api AM. Addendum to Fragrance material review on linalool. Food Chem Toxicol 2008; 46: 190-192

[76] Guzmán-Gutiérrez SL, Bonilla-Jaime H, Gómez-Cansino R, Reyes-Chilpa R. Linalool and $\beta$-pinene exert their antidepressant-like activity through the monoaminergic pathway. Life Sci 2015; 128: 24-29

[77] Mehri S, Meshki MA, Hosseinzadeh H. Linalool as a neuroprotective agent against acrylamide-induced neurotoxicity in Wistar rats. Drug Chem Toxicol 2015; 38: 162-166

[78] Sabogal-Guáqueta AM, Osorio E, Cardona-Gómez GP. Linalool reverses neuropathological and behavioral impairments in old triple transgenic Alzheimer's mice. Neuropharmacology 2016; 102: 111-120

[79] Wright BS, Bansal A, Moriarity DM, Takaku S, Setzer WN. Cytotoxic leaf essential oils from Neotropical Lauraceae: Synergistic effects of essential oil components. Nat Prod Commun 2007; 12: 1241-1244

[80] Skaltsa HD, Demetzos C, Lazari D, Sokovic M. Essential oil analysis and antimicrobial activity of eight Stachys species from Greece. Phytochemistry 2003; 64: 743-752

[81] Guo X, Shang X, Li B, Zhou XZ, Wen H, Zhang J. Acaricidal activities of the essential oil from Rhododendron nivale Hook. f. and its main compund, $\delta$-cadinene against Psoroptes cuniculi. Vet Parasitol 2017; 236: $51-54$

[82] Ruiz-Reyes E, Suarez M. Lactonas sesquiterpénicas. Diversidad estructural y sus actividades biológicas. Rev CENIC Cienc Biol 2015; 46: 9-24

[83] Rufino AT, Ribeiro M, Judas F, Salgueiro L, Lopes MC, Cavaleiro C, Mendes AF. Anti-inflammatory and chondroprotective activity of $(+)-\alpha$-pinene: structural and enantiomeric selectivity. J Nat Prod 2014; 77: 264-269

[84] Kim DS, Lee HJ, Jeon YD, Han YH, Kee JY, Kim HJ, Kang JW, Lee BS, Kim SH, Kim SJ, Park SH, Choi BM, Park SJ, Um SJ. Alpha-pinene exhibits antiinflammatory activity through the suppression of MAPKs and the NF- $\mathrm{KB}$ pathway in mouse peritoneal macrophages. Am J Chin Med 2015; 43: 731-742

[85] Pinheiro MA, Magalhães RM, Torres DM, Cavalcante RC, Mota FSX, Oliveira Coelho EM, Moreira HP, Lima GC, Araújo PCC, Cardoso JHL, Souza ANC, Diniz LRL. Gastroprotective effect of alpha-pinene and its correlation with antiulcerogenic activity of essential oils obtained from Hyptis species. Pharmacogn Mag 2015; 11: 123-130

[86] Aprotosoaie AC, Hăncianu M, Costache II, Miron A. Linalool: a review on a key odorant molecule with valuable biological properties. Flavour Fragr J 2014; 29: 193-219

[87] Raguso RA. More lessons from linalool: insights gained from a ubiquitous floral volatile. Curr Opin Plant Biol 2016; 32: 31-36 
[88] Silva LL, Balconi LS, Gressler LT, Garlet QI, Sutili F], Vargas AP, Baldisserotto B, Morel AF, Heinzmann BM. S-(+)-and $R$-(-)-linalool: a comparison of the in vitro anti-Aeromonas hydrophila activity and anesthetic properties in fish. An Acad Bra Ciênc 2017; 89: 203-212

[89] De Sousa DP, Nóbrega FF, Santos CC, de Almeida RN. Anticonvulsant activity of the linalool enantiomers and racemate: investigation of chiral influence. Nat Prod Commun 2010; 5: 1847-1851

[90] Barreiros ALS, David JM, David JP. Estresse oxidativo: relação entre geração de espécies reativas e defesa do organismo. Quím Nova 2006; 29: 113-123

[91] Chorilli M, Leonardi GR, Salgado HRN. Radicais livres e antioxidantes: conceitos fundamentais para aplicação em formulações farmacêuticas e cosméticas. Rev Bras Farmacogn 2007; 88: 113-118

[92] Halliwell B. The antioxidant paradox. Lancet 2000; 355: 1179-1180

[93] Finkel T, Holbrook NJ. Oxidants, oxidative stress and the biology of ageing. Nature 2000; 408: 239-247

[94] Phaniendra A, Jestadi DB, Periyasamy L. Free radicals: properties, sources, targets, and their implication in various diseases. Indian J Clin Biochem 2015; 30: 11-26

[95] Ferreira ALA, Matsubara LS. Radicais livres: conceitos, doenças relacionadas, sistema de defesa e estresse oxidativo. Rev Assoc Med Bras 1997; 43: 61-68

[96] Ramalho VC, Jorge N. Antioxidantes utilizados em óleos, gorduras e alimentos gordurosos. Quím Nova 2006; 29: 755-760

[97] González-Lamothe R, Mitchell G, Gattuso M, Diarra MS, Malouin F, Bouarab K. Plant antimicrobial agents and their effects on plant and human pathogens. Int J Mol Sci 2009; 10: 3400-3419

[98] Chanda S, Rakholiya K. Combination therapy: Synergism between natural plant extracts and antibiotics against infectious diseases. Microbiol Book Series 2011; 1: 520-529

[99] Kalemba D, Kunicka A. Antibacterial and antifungal properties of essential oils. Curr Med Chem 2003; 10: 813-829

[100] Burt SA. Essential oils: their antibacterial properties and potential applications in foods: a review. Int J Food Microbiol 2004; 94: 223-253

[101] Delaquis PJ, Stanich K, Girard B, Mazza G. Antimicrobial activity of individual and mixed fractions of dill, cilantro, coriander and eucalyptus essential oils. Int J Food Microbiol 2002; 74: 101-109

[102] Farnsworth NR. Biological and phytochemical screening of plants. J Pharm Sci 1996; 55: 225-276

[103] Zacchino S. Estratégia para a descoberta de novos agentes antifúngicos. In: Yunes RA, Calixto JB, editors. Plantas medicinais sob a ótica da química medicinal moderna. Chapecó: Argos; 2001: 435-479

[104] Antunes MDC, Cavacob A. The use of essential oils for postharvest decay control. A review. Flavour Fragr J 2010; 25: 351-366
[105] Gilles M, Zhao ], An M, Agboola S. Chemical composition and antimicrobial properties of essential oils of three Australian Eucalyptus species. Food Chem 2010; 119: 731-737

[106] Hammer KA, Carson CF, Riley TV. Antifungal effects of Melaleuca alternifolia (tea tree) oil and its components on Candida albicans, Candida glabrata and Saccharomyces cerevisiae. J Antimicrob Chemother 2004; 53: 1081-1085

[107] Pozzatti P, Scheid LA, Spader TB, Atayde ML, Santurio JM, Alves SH. In vitro activity of essential oils extracted from plants used as spices against fluconazole-resistant and fluconazole-susceptible Candida spp. Can J Microbiol 2008; 54: 950-960

[108] Stites DP, Terr Al, Parslow TG. Imunologia Médica. Rio de Janeiro: Guanabara Koogan; 2004: 684.

[109] Ferrero-Miliani L, Nielsen OH, Andersen PS, Girardin SE. Chronic inflammation: importance of NOD2 and NALP3 in interleukin-1beta generation. Clin Exp Immunol 2007; 147: 227-235

[110] Gomes A, Fernandes E, Lima JL, Mira L, Corvo ML. Molecular mechanisms of antiinflammatory activity mediated by flavonoids. Curr Med Chem 2008; 15: 1586-1605

[111] Miguel MG. Antioxidant and anti-inflammatory activities of essential oils: a short review. Molecules 2010; 15: 9252-9287

[112] Amarante CB, Müller AH, Póvoa MM, Dolabela MF. Estudo fitoquímico biomonitorado pelos ensaios de toxicidade frente à Artemia salina e de atividade antiplasmódica do caule de aninga (Montrichardia linifera). Acta Amaz 2011; 41: 431-434

[113] Riss TL, Moravec RA, Niles AL, Duellman S, Benink HA, Worzella TJ, Minor L. Cell Viability Assays. In: Sittampalam GS, Coussens NP, Brimacombe K, Grossman A, Auld D, Baell J, Caaveiro JMM, Chung TDY, Dahlin JL, Devanaryan V, Foley TL, Glicksman M, Hall MD, Haas JV, Inglese J, Iversen PW, Kahl SD, Kales SC, Lal-Nag M, Li Z, McGee J, Riss T, Trask J, Weidner JR, Wildey M], Xia M, Xu X, eds. Assay Guidance Manual [Internet]. Bethesda (MD): Eli Lilly \& Company and the National Center for Advancing Translational Sciences; 2004

[114] Setzer WN, Stokes SL, Penton AF, Takaku S, Haber WA, Hansell E, Caffrey CR, McKerrow JH. Cruzain inhibitory activity of leaf essential oils of Neotropical Lauraceae and essential oil components. Nat Prod Commun 2007; 2: 1203-1210

[115] Singh G, Maurya S, de Lampasona MP, Catalan CA. A comparison of chemical, antioxidant and antimicrobial studies of cinnamon leaf and bark volatile oils, oleoresins and their constituents. Food Chem Toxicol 2007; 45: 1650-1661

[116] Wu X, Vogler B, Haber WA, Setzer WN. A phytochemical investigation of Nectandra membranacea from Monteverde, Costa Rica. Nat Prod Commun 2006; 1: 465-468

[117] Takaku S, Haber WA, Setzer WN. Leaf essential oil composition of 10 species of Ocotea (Lauraceae) from Monteverde, Costa Rica. Biochem Syst Ecol 2007; 35: 525-532 